\title{
Mammalian $\mathrm{TAF}_{||} 30$ is required for cell cycle progression and specific cellular differentiation programmes
}

\section{Daniel Metzger, Elisabeth Scheer, Aleksey Soldatov ${ }^{1}$ and Làszlò Tora ${ }^{2}$}

\author{
Institut de Génétique et de Biologie Moléculaire et Cellulaire, \\ CNRS/INSERM/ULP, Collège de France, BP 163-67404 Illkirch \\ Cedex, CU de Strasbourg, France and Institute of Gene Biology, \\ Russian Academy of Sciences, Vavilov st. 26, Moscow 117 334, \\ Russia \\ ${ }^{2}$ Corresponding author \\ e-mail: laszlo@igbmc.u-strasbg.fr
}

The two alleles of the $30 \mathrm{kDa}$ TATA-binding protein associated factor $\left(\mathrm{TAF}_{\mathrm{II}} 30\right)$ gene, have been targeted by homologous recombination in murine $\mathrm{F} 9$ embryonal carcinoma cells and subsequently disrupted using a Cre recombinase-loxP strategy. The $\mathrm{TAF}_{\mathrm{II}} 30$-null cells are not viable, but are rescued by the expression of human $\mathrm{TAF}_{\mathrm{II}} 30$. Cells lacking $\mathrm{TAF}_{\mathrm{II}} 30$ are blocked in $G_{1} / G_{0}$ phase of the cell cycle and undergo apoptosis. In agreement with the $G_{1}$ arrest phenotype, the expression of cyclin $E$ is impaired and the retinoblastoma protein is hypophosphorylated in the $\mathrm{TAF}_{\mathrm{II}} 30$-null cells. Interestingly, retinoic acid (RA) treatment prevented TAF $_{\text {II }} 30$-null cell death and induced primitive endodermal differentiation. In contrast, the RA- and cAMPinduced parietal endodermal differentiation was impaired in the $\mathrm{TAF}_{\mathrm{II}} 30$-null cells. Thus, $\mathrm{TAF}_{\mathrm{II}} 30$ is not indispensable for class II gene transcription in general, but seems to be required for the expression of a subset of genes.

Keywords: apoptosis/conditional gene knock-out/Cre recombinase/proliferation/TFIID

\section{Introduction}

Correct initiation of transcription of protein-encoding genes by RNA polymerase II (Pol II) requires the transcription factor TFIID, which is comprised of TATA-binding protein (TBP) and a number of TBP-associated factors $\left(\mathrm{TAF}_{\mathrm{II}} \mathrm{s}\right)$ (Tansey and Herr, 1997). The exact role of $\mathrm{TAF}_{\mathrm{II}} \mathrm{S}$ in transcription initiation is unknown. Initial in vitro transcription studies suggested that $\mathrm{TAF}_{\mathrm{II}} \mathrm{S}$ may work as general co-activators to mediate the transcriptional activation of the different activators (Goodrich et al., 1996). It was also shown that recombinant TBP can substitute in vitro for TFIID in reconstituted transcription systems, but does not support transcription from TATAless promoters (Pugh and Tjian, 1991; Zhou et al., 1992).

Evidence that $\mathrm{TAF}_{\mathrm{II}} \mathrm{S}$ function as co-activators in mammalian cells has been provided by studies showing that hTAF $_{\text {II }} 28$ and hTAF $_{\text {II }} 135$ enhance transcriptional activation by nuclear receptors (May et al., 1996; Mengus et al., 1997). Further evidence that $\mathrm{TAF}_{\mathrm{II}} \mathrm{S}$ are required for transcriptional activation came from genetic studies of
D.melanogaster which showed that mutations in $\mathrm{dTAF}_{\mathrm{II}} \mathrm{S}$ lead to specific defects in transcriptional activation in the embryo (Zhou et al., 1998).

In yeast $(\mathrm{y})$ strains lacking functional $\mathrm{yTAF}_{\mathrm{II}} \mathrm{S}$, a variety of inducible genes are normally transcribed in vivo (Apone et al., 1996; Moqtaderi et al., 1996a; Walker et al., 1996). Nevertheless, TAF $_{\text {II }}$ s do play an essential role in yeast, as mutant strains are not viable (Moqtaderi et al., 1996b). Thus, $\mathrm{TAF}_{\mathrm{II}} \mathrm{S}$ may not generally be required for activatordependent transcription, but seem to be essential for the transcription of certain genes.

Functionally distinct TFIID populations, sharing common $\mathrm{TAF}_{\mathrm{II}} \mathrm{S}$ but differing in their specific $\mathrm{TAF}_{\mathrm{II}}$ composition, have been isolated from mammalian cells (Bell and Tora, 1999). TFIID complexes that either contain (TFIID $\beta$ ) or lack (TFIID $\alpha)$ hTAF $_{\text {II }} 30$ have been separated from mammalian cells extracts (Jacq et al., 1994; Mengus et al., 1995). Human $\mathrm{TAF}_{\mathrm{II}} 30$ is present in only $~ 50 \%$ of TFIID complexes and is therefore considered a 'specific' TAF $_{\text {II }}$ (Jacq et al., 1994). Recently, a novel multiprotein complex containing neither TBP nor TBP-like factor (TLF), but comprising $\mathrm{hTAF}_{\mathrm{II}} 30$ and several other $\mathrm{TAF}_{\mathrm{II}} \mathrm{s}$, has been characterized (Wieczorek et al., 1998). This complex, called TBP-free $\mathrm{TAF}_{\mathrm{II}}$-containing complex (TFTC), can replace TFIID in in vitro transcription assays (Wieczorek et al., 1998) and contains histone acetyl transferase (HAT) activity (Brand et al., 1999). Moreover, $\mathrm{TAF}_{\mathrm{II}} 30$ and its yeast homologue $\mathrm{yTAF}_{\mathrm{II}} 25$ are present in several other TAF $_{\text {II }}$-HAT-containing complexes, the yeast SAGA and the human PCAF/GCN5 complexes (Grant et al., 1998; Ogryzko et al., 1998).

To understand the functions of mammalian $\mathrm{TAF}_{\mathrm{II}} \mathrm{S}$ in the regulation of Pol II transcription in vivo, and more specifically that of $\mathrm{TAF}_{\mathrm{II}} 30$, we have inactivated both alleles of the $T A F_{I I} 30$ gene in murine embryonal carcinoma F9 cells. The F9 cell line provides an interesting model system to analyse the role of a given transcription factor during either cell proliferation and/or cell differentiation. Treatment of F9 cells with all-trans retinoic acid (RA) induces primitive endodermal differentiation (Strickland and Mahdavi, 1978), whereas treatment with RA and dibutyryl c-AMP $\left(\mathrm{bt}_{2} \mathrm{cAMP}\right)$ induces a parietal endodermal phenotype (Strickland et al., 1980). Moreover, the RAinduced differentiation of F9 cells is accompanied by a dramatic decrease in the proliferation rate, an increase in the fraction of cells arrested in $G_{1} / G_{0}$ phase of the cell cycle and an increase in the number of apoptotic cells (Clifford et al., 1996, and references therein). The RAinduced differentiation is mediated by the RA receptors (RARs) and the retinoic X receptors (RXRs) (Chiba et al., 1997a, and references therein). The two $T A F_{I I} 30$ alleles have been targeted here by homologous recombination (HR) and subsequently disrupted by using a Cre recombinase-loxP strategy (Sauer and Henderson, 1990). F9 cells 
with both $T A F_{I I} 30$ alleles inactivated are not viable, but can be rescued by expression of human $\mathrm{TAF}_{\mathrm{II}} 30$. Furthermore, we present evidence that $\mathrm{TAF}_{\mathrm{II}} 30$ is required for cell cycle progression through $\mathrm{G}_{1}$ phase. $\mathrm{TAF}_{\mathrm{II}} 30$-null cells undergo massive apoptosis which is prevented by RA-induced differentiation. Interestingly, parietal, but not primitive endodermal differentiation is strongly impaired in the $\mathrm{TAF}_{\mathrm{II}} 30$-null cells. Taken together, our results indicate that $\mathrm{TAF}_{\mathrm{II}} 30$ plays an important and selective role in establishing gene expression patterns.

\section{Results}

\section{Conditional targeting of the $\mathrm{TAF}_{\mid / 3} 30$ gene in F9 cells}

To inactivate the $T A F_{I I} 30$ gene by $\mathrm{HR}$, we first cloned and characterized the mouse gene (Figure 1). The structure of the mouse $(m) T A F_{I I} 30$ gene is very similar to the human $\mathrm{TAF}_{\mathrm{II}} 30$ gene (TAF2H; Scheer et al., 1995), i.e. it consists of five exons (Figure 1). The $m T A F_{I I} 30$ coding sequence deduced from the genomic sequence is 759 bases long (89\% identical to the human cDNA) and encodes a 218 amino acid protein that is $90.3 \%$ identical to the human $\mathrm{TAF}_{\mathrm{II}} 30$ protein.

To perform a conditional disruption of the $m T A F_{I I} 30$ gene in F9 cells, we used a Cre-loxP strategy, similar to that previously described (Sumi-Ichinose et al., 1997). We constructed two targeting vectors (Figure 1B and C), in which a loxP site (hereafter termed L) was inserted into the intron located upstream of exon 2, while a neomycinresistance gene expression cassette (tk-neo, hereafter termed N) flanked by two loxP sites ('floxed') was inserted into the intron located downstream of exon 2. Thus, following targeting of the wild-type (WT) alleles by HR, the Cre recombinase will allow the excision of exon 2 as well as the floxed selection marker cassette, resulting in the deletion of the sequences encoding amino acid residues 78 (alanine) to 130 (isoleucine) and the creation of a frame shift in the beginning of exon 3 with a stop codon (Figure 1 and data not shown). Thus, the putative truncated protein produced from the disrupted gene will lack the evolutionary highly conserved C-terminal domain of $\mathrm{TAF}_{\mathrm{II}} 30$.

To target the first allele of the $T A F_{I I} 30$ gene, F9 cells were electroporated with the pTAF $_{\mathrm{II}} 30^{(\mathrm{L}: \mathrm{LNL}) \mathrm{a}}$ vector (Figure 1B). Southern blotting and genomic PCR analyses revealed clones that had one targeted $T A F_{I I} 30$ allele $\left[\mathrm{TAF}_{\mathrm{II}} 30^{(\mathrm{L}: \mathrm{LNL}) \mathrm{a} /+}\right.$; see Figures $1 \mathrm{~B}, 2 \mathrm{~A}$ and $\left.\mathrm{C}\right]$. As the presence of the marker gene in the targeted MTAF $_{I I} 30$ allele might affect its expression, we established a cell line in which the floxed neomycin-resistance gene was excised before targeting the second allele. To this end, $\mathrm{TAF}_{\mathrm{II}} 30^{\text {(L:LNL)a/+ }}$ cells were electroporated with the Cre recombinase expression vector. Clones were obtained in which either exon 2 and the selection marker cassette $\left(\mathrm{TAF}_{\mathrm{II}} 30^{-\mathrm{La} /+}\right.$ cells) or only the selection marker cassette $\left[\mathrm{TAF}_{\mathrm{II}} 30^{(\mathrm{L}: \mathrm{L}) \mathrm{a} /+}\right.$ cells] were deleted (see Figure $2 \mathrm{~A}$ and C). Cells from one of the $\mathrm{TAF}_{\mathrm{II}} 30^{\text {(L:L)a/+ }}$ clones were then electroporated with the second targeting vector (Figure 1C) and cells containing the second targeted $T A F_{I I} 30$ allele were identified (Figures 1, $2 \mathrm{~B}$ and $\mathrm{C}$ ). Note that in the second targeting vector, the three loxP sites were in the opposite orientation when compared with the previously used vector.

To excise the sequences located between the loxP sites, the $\mathrm{TAF}_{\mathrm{II}} 30^{(\mathrm{L}: \mathrm{L}) \mathrm{a} /(\mathrm{L}: \mathrm{LNL}) \mathrm{b}}$ cells (Figure $2 \mathrm{~B}$ ) were electroporated with the Cre recombinase expression vector. No clones with both alleles inactivated $\left[\mathrm{TAF}_{\mathrm{II}} 30^{-\mathrm{La} /-\mathrm{Lb}}\right.$ or TAFII $30^{-\mathrm{La} /-(\mathrm{LNL}) \mathrm{b}}$ ] were obtained out of 560 analysed clones, but 30 clones had one inactivated $T A F_{I I} 30$ allele (Figure 2B). Amongst these clones, all the possible different genotypes for the two $T A F_{I I} 30$ alleles were present (Figure $2 \mathrm{~B}$ and $\mathrm{C}$ and data not shown). Thus, it appears that either one of the two alleles of the mouse $T A F_{I I} 30$ gene can be independently inactivated, but that inactivation of both $\mathrm{TAF}_{\mathrm{II}} 30$ alleles may be lethal.

\section{Inactivation of both TAF /,30 alleles impairs F9 cell viability}

To investigate whether the inactivation of both $T A F_{I I} 30$ alleles impairs the proliferation of F9 cells, $\mathrm{TAF}_{\mathrm{II}} 30^{-\mathrm{La} /(\mathrm{L}: \mathrm{L}) \mathrm{b}}$ cells were electroporated with the Cre recombinase expression vector and the cell population was genotyped by PCR using DNA extracted over an 11 day period (Figure 3 ). Southern blotting was used for the detection of the (L:L)b and $-\mathrm{Lb}$ alleles (Figure 3B). The intensity of the $706 \mathrm{bp}$ signal corresponding to the (L:L)b allele was similar in all the samples analysed. In contrast, although the $233 \mathrm{bp}$ signal corresponding to the Lb allele could be detected 1 day after Cre recombinase electroporation, it decreased at day four, and finally disappeared totally between days five and seven (Figure 3B and data not shown). Thus, F9 cells with both $\mathrm{TAF}_{\mathrm{II}} 30$ alleles inactivated were obtained, but were apparently severely affected in their proliferation and could not be cloned.

\section{Conditional rescue of $T A F_{\| / 30^{-L a /-L b}}$ cells with human $T F_{||} 30$}

To demonstrate unequivocally that the failure to obtain an F9 cell line in which both $m T A F_{I I} 30$ alleles are inactivated, was due to an absolute requirement of the $\mathrm{TAF}_{\mathrm{II}} 30$ protein for cell proliferation, and to allow further studies of $\mathrm{TAF}_{\mathrm{II}} 30$ function, we generated a Dox-inducible $\mathrm{TAF}_{\mathrm{II}} 30$ expression system. We stably integrated an expression cassette encoding the reverse tetracycline-controlled transactivator (rtTA; Gossen et al., 1995) in the genome of the $\mathrm{TAF}_{\mathrm{II}} 30^{-\mathrm{La} /(\mathrm{L}: \mathrm{L}) \mathrm{b}}$ cells, as well as another cassette in which the human $T A F_{I I} 30$ cDNA is under the control of tetracycline-operators, resulting in the $\mathrm{TAF}_{\mathrm{II}} 30^{-\mathrm{La} /(\mathrm{L}: \mathrm{L}) \mathrm{b}}: \mathrm{R}$ cell line. The inducibility of $\mathrm{hTAF}_{\mathrm{II}} 30$ protein synthesis by the tetracycline analogue Dox was verified by Western blotting analysis using the anti-hTAF 30 monoclonal antibody 2F4 (Jacq et al., 1994), which is specific for the human protein. Whereas no $\mathrm{hTAF}_{\mathrm{II}} 30$ protein could be detected in $\mathrm{TAF}_{\mathrm{II}} 30^{-\mathrm{La} /(\mathrm{L}: \mathrm{L}) \mathrm{b}}: \mathrm{R}$ F9 cells grown in the absence of Dox, the amount of $\mathrm{hTAF}_{\mathrm{II}} 30$ protein after Dox treatment of these cells was comparable to that of mTAF $_{\mathrm{II}} 30$ in WT F9 cells (Figure 3C). To inactivate both $m T A F_{I I} 30$ alleles, $\mathrm{TAF}_{\mathrm{II}} 30^{-\mathrm{La} /(\mathrm{L}: \mathrm{L}) \mathrm{b}}: \mathrm{R}$ cells were electroporated with the Cre recombinase expression vector and cultured in the presence of Dox. Under these conditions we obtained several clones in which exon 2 was deleted on both alleles, as verified by Southern blotting and genomic PCR analyses $\left(\mathrm{TAF}_{\mathrm{II}} 30^{-\mathrm{La} / \mathrm{Lb}}: \mathrm{R}\right.$; Figure 3D). Inter- 


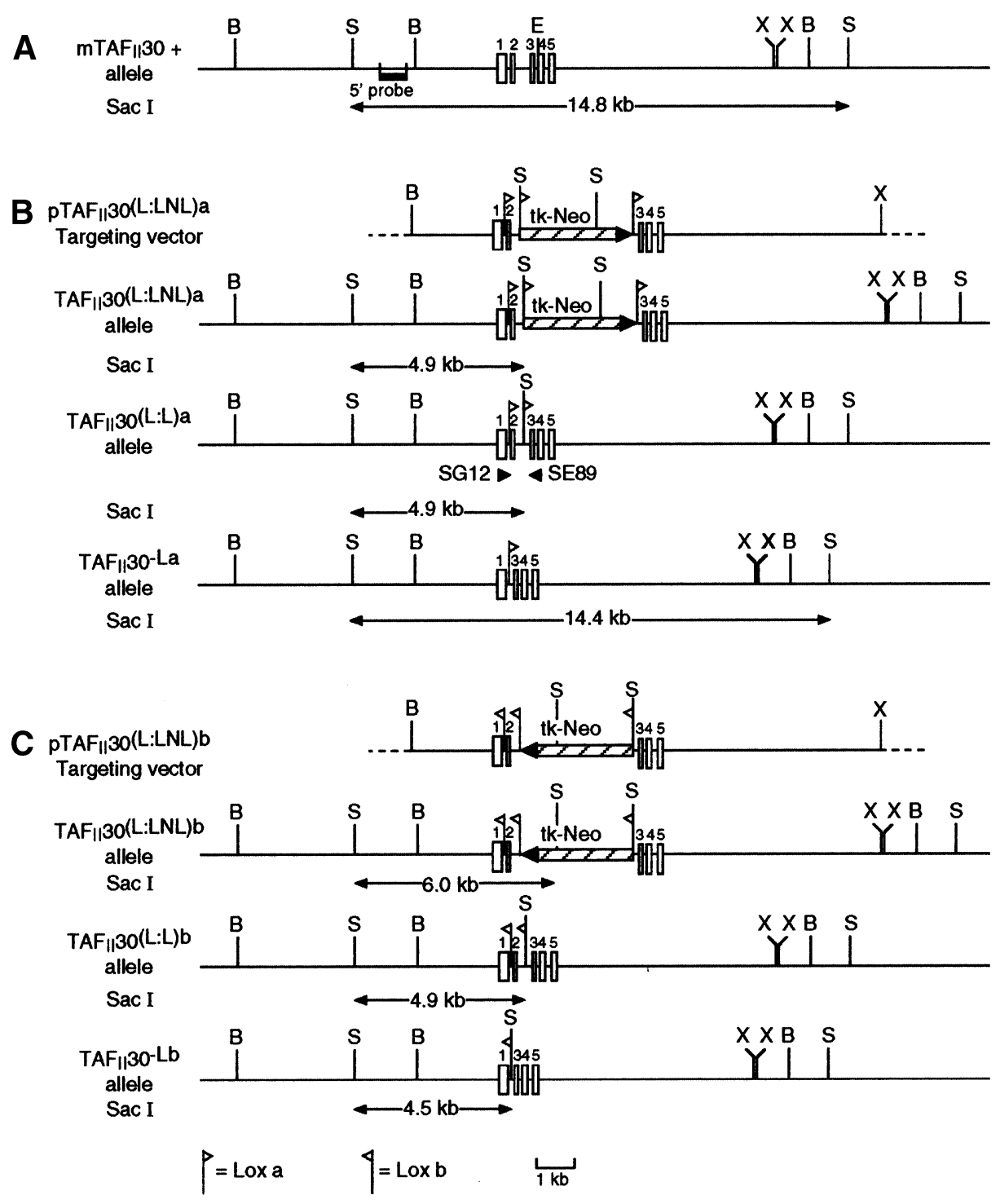

Fig. 1. Strategy for targeting the mouse $T A F_{I I} 30$ gene. (A) Structure of the mouse $T A F_{I I} 30$ gene $\left(\mathrm{mTAF}_{I I} 30^{+}\right.$allele). Exons 1 to 5 , and the $5^{\prime}$ probe corresponding to a $0.8 \mathrm{~kb} E c o \mathrm{RV}-K p n \mathrm{I}$ fragment are indicated. (B) First allele targeting. The targeting vector $\mathrm{pTAF}_{\mathrm{II}} 30^{(\mathrm{L}: \mathrm{LNL}) \mathrm{a}}$ is represented. The loxP sites (open triangles) and the tk-Neo cassette (tk-Neo) are indicated. The expected genomic maps after HR [TAF ${ }_{\text {II }} 30^{(\mathrm{L}: \mathrm{LNL}) \mathrm{a}}$ allele] and Cre-mediated excision of loxP-flanked DNA segments $\left[\mathrm{TAF}_{\mathrm{II}} 30^{\mathrm{L}: \mathrm{L}) \mathrm{a}}\right.$ and $\mathrm{TAF}_{\mathrm{II}} 30^{-\mathrm{La}}$ alleles] are shown. (C) Second allele targeting. The targeting vector $\mathrm{pTAF}_{\mathrm{II}} 30^{(\mathrm{L}: \mathrm{LNL}) \mathrm{b}}$ is represented. The loxP sites (open triangles) and the tk-Neo cassette, in opposite orientations relative to those in the $\mathrm{pTAF}_{\mathrm{II}} 30^{(\mathrm{L}: \mathrm{LNL}) \mathrm{a}}$ vector, are indicated. The expected genomic maps after HR [TAF $30^{(\mathrm{L}: \mathrm{LNL}) \mathrm{b}}$ allele] and Cre-mediated excision of loxP-flanked DNA segments $\left[\mathrm{TAF}_{\mathrm{II}} 30^{(\mathrm{L}: \mathrm{L}) \mathrm{b}}\right.$ and $\mathrm{TAF}_{\mathrm{II}} 30^{-\mathrm{Lb}}$ alleles] are shown. The horizontal arrowheads indicate the location of the primers used for PCRs (see Figures 2C and 3D). DNA fragments obtained after SacI-digestion and detection with the $5^{\prime}$ probe (see Figures 2C and 3D) are also indicated: B, BamHI; S, SacI; X, XhoI; and E, EcoRI (E is only indicated in the $\mathrm{mTAF}_{\mathrm{II}} 30^{+}$allele). The solid line in the targeting vectors corresponds to the DNA fragment used for gene targeting. Dotted lines represent plasmid sequences.

estingly, in the $\mathrm{TAF}_{\mathrm{II}} 30^{-\mathrm{La} /-\mathrm{Lb}}: \mathrm{R}$ cells neither a truncated $m T A F_{I I} 30$ mRNA nor a truncated protein could be detected by Northern and Western blotting analyses, respectively (Figure 3D). Therefore, the $-\mathrm{La}$ and $-\mathrm{Lb}$ alleles are true null alleles.

To investigate the role of $\mathrm{TAF}_{\mathrm{II}} 30$ in cell proliferation, we cultured the $\mathrm{TAF}_{\mathrm{II}} 30^{-\mathrm{La} /-\mathrm{Lb}}: \mathrm{R}$ cells in the absence and presence of Dox. One day after Dox withdrawal, the hTAF $_{\mathrm{II}} 30$ protein level decreased by $\sim 50 \%$ and became undetectable from the second day after Dox withdrawal (Figure 4A), whereas in the presence of Dox the $\mathrm{hTAF}_{\mathrm{II}} 30$ levels were constant over several weeks (Figure 4A and data not shown). The growth rates of $\mathrm{TAF}_{\mathrm{II}} 30^{-\mathrm{La} /-\mathrm{Lb}}: \mathrm{R}$ cells grown either in the presence or absence of Dox were similar for the first 2 days, but in the absence of Dox the cells became arrested after 3 days, and almost all the cells were dead after 6 days. Whereas cells grew to confluency in the presence of Dox [Figures 4B and 7A (b) and (c)]. Taken together, these results demonstrate that the $T A F_{I I} 30$ gene product is indispensable for the viability of undifferentiated F9 cells.

Interestingly, even 5 days after Dox withdrawal, the protein levels of other TFIID and TFTC components (such as $\mathrm{mTBP}$ and $\mathrm{mTAF}_{\mathrm{II}} 135, \mathrm{mTAF}_{\mathrm{II}} 100, \mathrm{mTAF}_{\mathrm{II}} 80$ and $\left.\mathrm{mTAF}_{\mathrm{II}} 55\right)$ were not affected in $\mathrm{TAF}_{\mathrm{II}} 30$-null cells (Figure 4A and data not shown). 

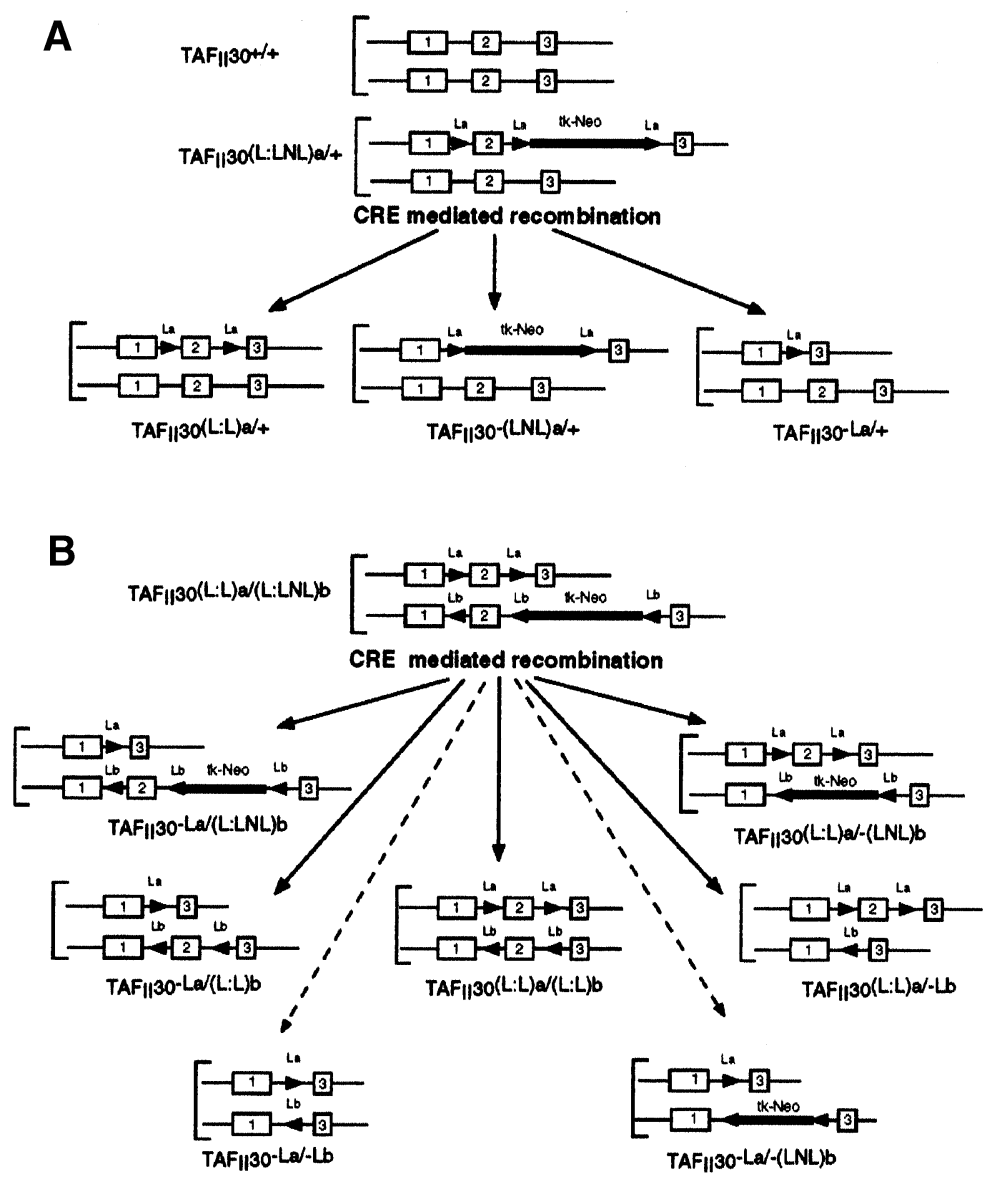

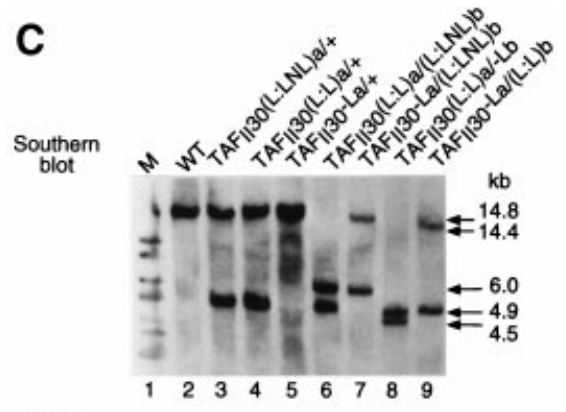

PCR

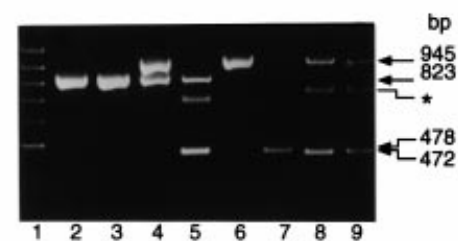

Fig. 2. Nomenclature and characterization of the genotypes of the different F9 cell lines targeted in the $T A F_{I I} 30$ locus. Schematic representation of the different $\mathrm{TAF}_{\mathrm{II}} 30$ mutant cell lines obtained after targeting the first $(\mathbf{A})$ and the second $(\mathbf{B})$ alleles and after Cre-mediated recombination. The exons are represented as boxes (1-3) and the loxP sites in orientation a (La) or b (Lb) as triangles. The genotypes of cells indicated by dotted arrows were not obtained. (C) Southern blot of SacI-digested genomic DNA from the different cell lines (as indicated) hybridized with the $5^{\prime}$ probe (see Figure 1). Lane 2, +/+ (14.8 kb); lane 3, (L:LNL)a/+ (4.9 and $14.8 \mathrm{~kb})$; lane 4, (L:L)a/+ (4.9 and $14.8 \mathrm{~kb})$; lane 5, $-\mathrm{La} /+(14.4 \mathrm{and} 14.8 \mathrm{~kb})$; lane 6, (L:L)a/(L:LNL)b (4.9 and $6 \mathrm{~kb})$; lane 7, -La/(L:LNL)b (14.4 and $6 \mathrm{~kb})$; lane 8, (L:L)a/-Lb (4.9 and 4.5 kb); and lane 9, -La/(L:L)b (14.4 and $4.5 \mathrm{~kb}$ ). Genomic DNA extracted from the indicated cell lines was analysed by PCR using the primers indicated in Figure 1B. The SG12-SE89 primer pair amplifies an $823 \mathrm{bp}$ fragment from the WT and the (L:LNL)a/ + alleles (lanes 2 and 3), 945 and 823 bp fragments from the (L:L)a/ + alleles (lane 4), 823 and $478 \mathrm{bp}$ fragments from the -La/+ alleles (lane 5), $945 \mathrm{bp}$ fragment from the (L:L)a/(L:LNL)b alleles (lane 6), $478 \mathrm{bp}$ fragment from -La/(L:LNL)b alleles (lane 7), 472 and 945 bp fragments from the (L:L)a/-Lb alleles (lane 8), and 478 and 945 bp fragments from the $-\mathrm{La} /(\mathrm{L}: \mathrm{L}) \mathrm{b}$ alleles (lane 9), respectively. The * indicates a non specific band. The $1 \mathrm{~kb}$ ladder DNA (M; Gibco-BRL) is shown in lane 1.

\section{$T A F_{\mid l} 30$ is required for $G_{1}-S$ phase cell cycle progression}

The cell cycle profile of the $\mathrm{TAF}_{\mathrm{II}} 30^{-\mathrm{La} / \mathrm{Lb}}: \mathrm{R}$ cells grown in the absence or presence of Dox was investigated by flow cytometry. In agreement with the proliferation rate studies (Figure 4B), no significant differences in the cell cycle profiles were seen between $\mathrm{TAF}_{\mathrm{II}} 30^{-\mathrm{L} a}-\mathrm{Lb}: \mathrm{R}$ cells grown for 2 days in the absence or presence of Dox (Figure 4C). In contrast, 5 days after Dox withdrawal the $\mathrm{TAF}_{\mathrm{II}} 30$-null cells accumulated in $\mathrm{G}_{1} / \mathrm{G}_{0}$ phase. The proportion of cells in $\mathrm{G}_{1} / \mathrm{G}_{0}$ phase increased from $\sim 39$ to $61 \%$ (Figure 4C).

We then investigated the mRNA level of different cell cycle-related cyclin genes in $\mathrm{TAF}_{\mathrm{II}} 30$-null cells. Reverse transcription-polymerase chain reaction (RT-PCR) analysis was used to obtain a semi-quantitative estimation of the expression of different genes (see Materials and methods). Cyclin E expression was progressively reduced from the third to the fifth day after Dox withdrawal ( 6.6fold reduction at the fifth day), when compared with either the expression in cells grown in the presence of Dox or
WT cells (Figure 5A and B). In contrast, the expression of the other tested cyclins was either not, or was only weakly altered after the suppression of $\mathrm{hTAF}_{\mathrm{II}} 30$ synthesis (Figure 5A and B). Cyclin E, which is expressed at maximal levels in the $\mathrm{G}_{1}-\mathrm{S}$ transition and interacts with its catalytic partner $c d k 2$, is a key regulator of $\mathrm{G}_{1}$ progression during the cell cycle (Sherr, 1994; Reed, 1997). The strong reduction of cyclin $\mathrm{E}$ expression in $\mathrm{TAF}_{\mathrm{II}} 30$-null cells is in good agreement with the results obtained by flow cytometry indicating that $\mathrm{TAF}_{\mathrm{II}} 30$-null cells accumulate in $\mathrm{G}_{1}$ phase.

Phosphorylation of retinoblastoma protein $(\mathrm{pRb})$ in $\mathrm{G}_{1}$ inactivates its growth inhibitory function, allowing cell cycle progression (Bartek et al., 1997). As cyclin E$c d k 2$ complex collaborates with the D-type cyclin-cdk4/6 complexes for $\mathrm{pRb}$ phosphorylation (Hatakeyama et al., 1994; Lundberg and Weinberg, 1998), we investigated the phosphorylation state of $\mathrm{pRb}$ in the $\mathrm{TAF}_{\mathrm{II}} 30$-null cells. In WT and $\mathrm{TAF}_{\mathrm{II}} 30^{-\mathrm{La} / \mathrm{Lb}}: \mathrm{R}$ cells expressing $\mathrm{hTAF}_{\mathrm{II}} 30$ protein, $\sim 70 \%$ of $\mathrm{pRb}$ was phosphorylated (Figure 5C, lanes 1 and 2). In contrast, the level of pRb phosphorylation 
A

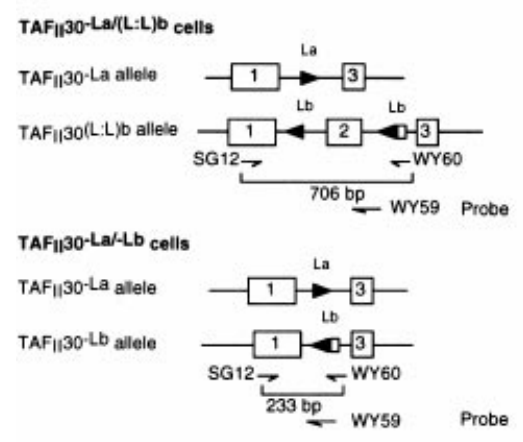

C

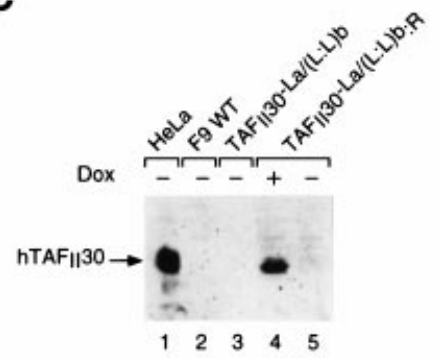

B

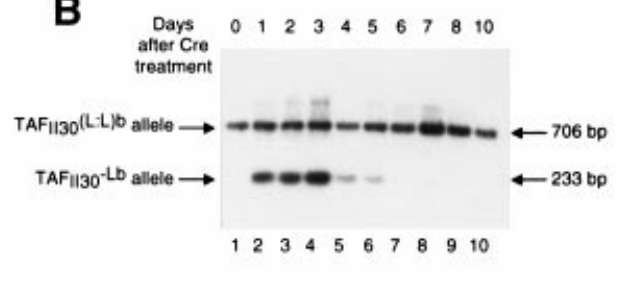

D
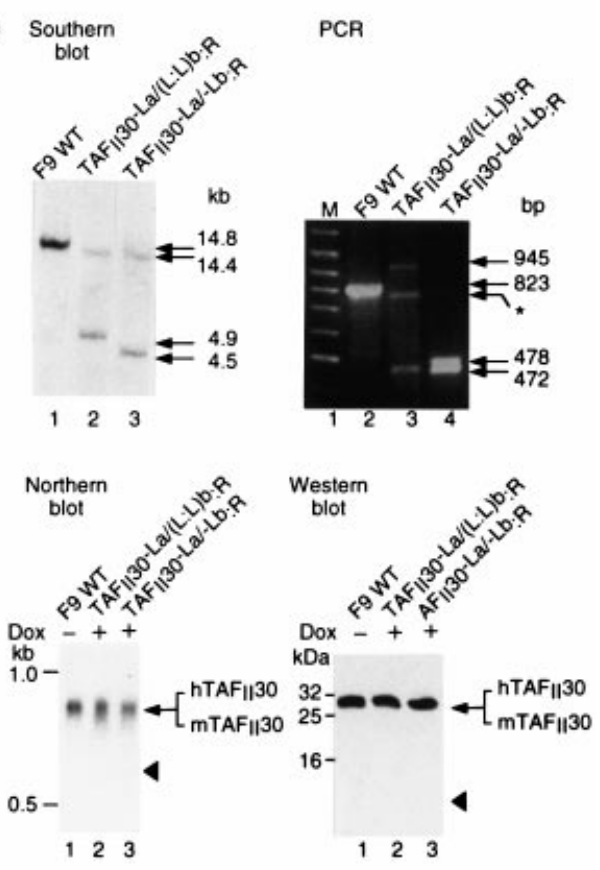

Fig. 3. $\mathrm{TAF}_{\mathrm{II}} 30^{-\mathrm{La} / \mathrm{Lb}}$ cells are not viable, but can be rescued by human $\mathrm{TAF}_{\mathrm{II}}$ 30. (A) The PCR strategy to identify the different alleles is outlined. Exons are indicated as numbered boxes. LoxP sites in orientation a (La) are indicated as black triangles. The oligonucleotides used either as PCR primers (SG12 and WY60; see Materials and methods) or as a probe WY59 (5'-GGAGGGCATCGTCGACATAA-3') are represented by arrows. The loxP site in orientation $\mathrm{b}(\mathrm{Lb})$ with its surrounding sequences, and recognized by the PCR primer WY60, is shown as black triangles fused to an open box. The length of the amplified fragments from the different alleles is given. (B) Detection of $\mathrm{TAF}_{\mathrm{II}} 30^{-\mathrm{La} /-\mathrm{Lb}}$ cells by PCR. TAF $\mathrm{T}_{\mathrm{II}} 30^{-\mathrm{La} /(\mathrm{L}: \mathrm{L}) \mathrm{b}}$ cells were electroporated with the pSG-Cre expression vector, plated at a density of $2.5 \times 10^{3}$ cells/well in 6-well plates and collected from days zero to 10 and stored at $-80^{\circ} \mathrm{C}$. Detection of the $\mathrm{TAF}_{\mathrm{II}} 30^{(\mathrm{L} / \mathrm{L}) \mathrm{b}}$ and $\mathrm{TAF}_{\mathrm{II}} 30^{-\mathrm{Lb}}$ alleles was performed according to the Materials and methods, as depicted in (A). (C) Dox-induced expression of $\mathrm{hTAF}_{\mathrm{II}} 30$ in $\mathrm{TAF}_{\mathrm{II}} 30^{-\mathrm{La} / \mathrm{L}: \mathrm{L}) \mathrm{b}}: \mathrm{R}$ cells. Cell extracts were prepared from cells grown in the presence or absence of Dox, as well as from HeLa and F9 cells, as indicated. Twenty-five microgrammes of each protein extract was loaded per lane and analysed by Western blotting using the anti-hTAF 30 monoclonal antibody 2F4 (Jacq et al., 1994), which is specific for the human protein. (D) Characterization by Southern, Northern and Western blotting and PCR amplification of $\mathrm{TAF}_{\mathrm{II}} 30^{-\mathrm{La} / \mathrm{Lb}}: \mathrm{R}$ cells. Southern blotting was performed on SacI-digested genomic DNA isolated from the different cell lines (as indicated), and hybridized with the $5^{\prime}$ probe (see Figure 1). Lane 1, WT (14.8 kb); lane 2, $-\mathrm{La} /(\mathrm{L}: \mathrm{L}) \mathrm{b}(14.4$ and $4.5 \mathrm{~kb})$; and lane 3, $-\mathrm{La} /-\mathrm{Lb}(14.4$ and $4.5 \mathrm{~kb})$. Genomic DNA extracted from the indicated cell lines was analysed by PCR using the primers indicated in Figure 1B. The SG12-SE89 primer pair amplifies an 823 bp fragment from the WT alleles (lane 2), 945 and 472 bp fragments from the $-\mathrm{La} /(\mathrm{L}: \mathrm{L}) \mathrm{b}$ alleles (lane 3), and 472 and $478 \mathrm{bp}$ fragments from the $-\mathrm{La} /-\mathrm{Lb}$ alleles (lane 4), respectively. The asterisk indicates a non specific band. The $1 \mathrm{~kb}$ ladder DNA (M; Gibco-BRL) is shown in lane 1. The Northern blotting was carried out by standard methods using cytoplasmic RNA isolated from the indicated cell lines and hybridized with a mTAF 30 cDNA probe. The Western blotting was carried out with protein extracts isolated from the indicated cell lines using the $1 \mathrm{H} 8$ anti- $\mathrm{TAF}_{\mathrm{II}} 30 \mathrm{mAb}$, directed against the $\mathrm{N}$-terminal end of TAF 30 (Wieczorek et al., 1998). The arrowheads on the Northern and Western blots indicate the sizes of the putative truncated mTAF 30 RNA and protein, respectively.

decreased after stopping $\mathrm{hTAF}_{\mathrm{II}} 30$ expression, and after 5 days of culture in the absence of Dox, pRb was essentially unphosphorylated (Figure 5C, lane 6). Note that the expression of pRb mRNA was not affected in the $\mathrm{TAF}_{\mathrm{II}} 30$-null cells (data not shown). Taken together, the above results show that $\mathrm{TAF}_{\mathrm{II}} 30$ is required for $\mathrm{G}_{1}-\mathrm{S}$ phase cell cycle progression and cyclin E expression.

\section{TAF, 30-null F9 cells undergo apoptosis}

When the $\mathrm{TAF}_{\mathrm{II}} 30^{-\mathrm{La} /-\mathrm{Lb}}: \mathrm{R}$ cells were grown for 5 days in the absence of Dox, $\sim 82 \%$ of the cells had a sub- $2 \mathrm{~N}$ size DNA content, whereas only $\sim 6 \%$ of such particles were detected in the presence of Dox, suggesting that most of the $\mathrm{TAF}_{\mathrm{II}}$ 30-lacking cells die by apoptosis (Figure 4C). During apoptosis endonucleases that preferentially cut DNA are activated. The characteristic DNA 'ladder' of fragmented DNA appeared 4 days after growing the $\mathrm{TAF}_{\mathrm{II}} 30^{-\mathrm{La} /-\mathrm{Lb}}: \mathrm{R}$ cells in the absence of Dox and its amount increased with time (Figure 6C, lanes 17, 21 and 25). The translocation of the membrane phospholipid phosphatidylserine (PS) from the inner to the outer leaflet of the plasma membrane is another feature of apoptotic cells. Annexin V binds specifically to PS of cells and therefore allows detection of cells early in apoptosis (Philippe et al., 1997). To distinguish early apoptotic from late apoptotic cells we used annexin $\mathrm{V}$ in combination with 

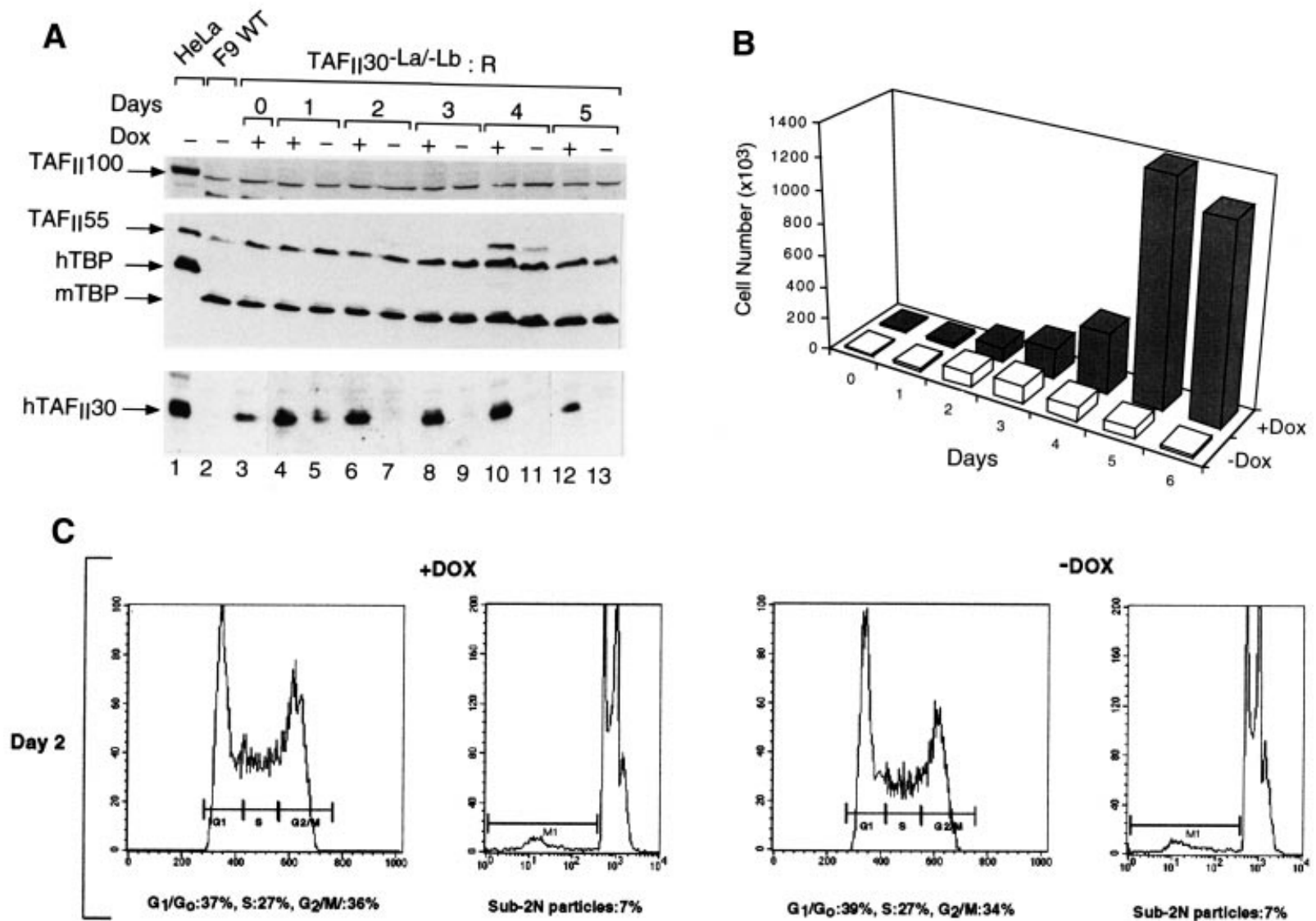

+ DOX
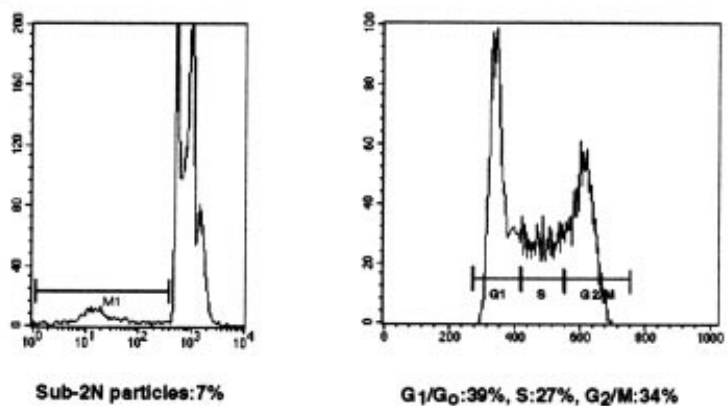

-DOX

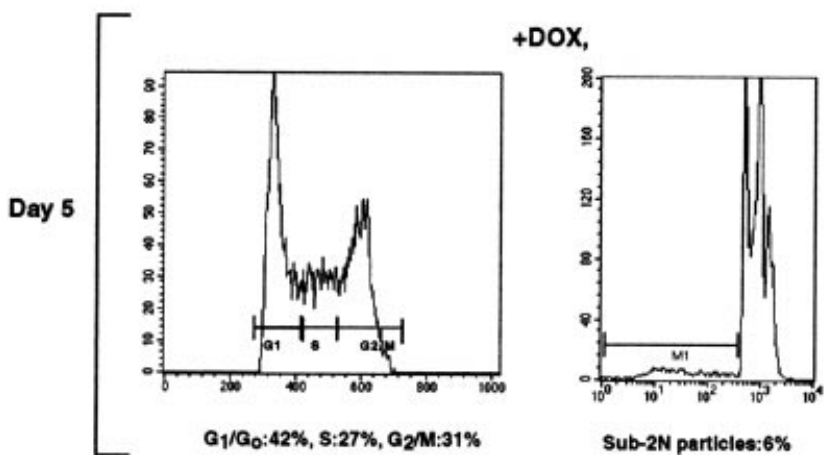

$G_{1} / G_{0}: 39 \%, S: 27 \%, G_{2} / M: 34 \%$
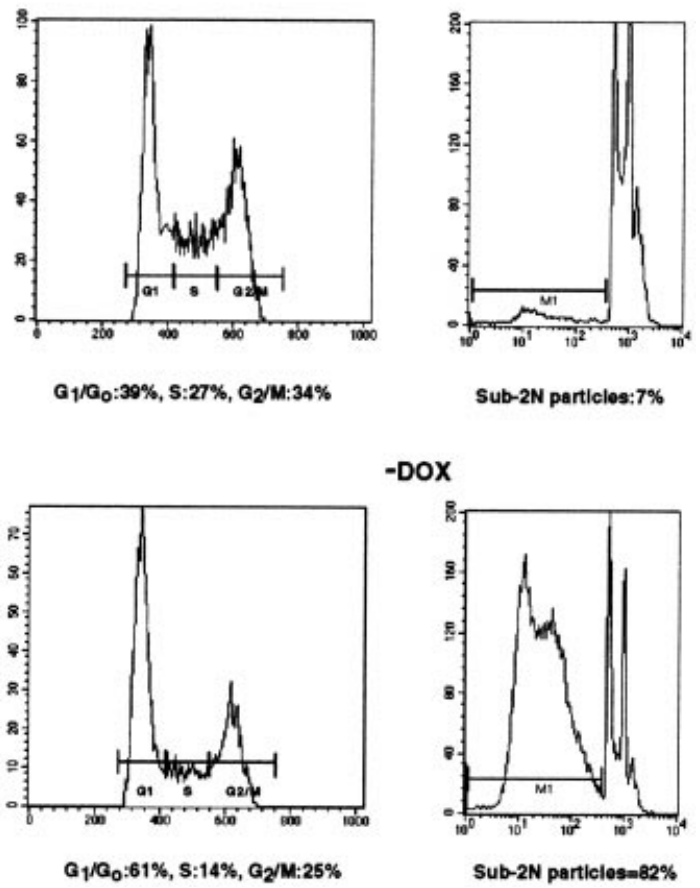

Sub-2N particlesm $82 \%$

Fig. 4. $\mathrm{TAF}_{\mathrm{II}} 30$-null cells are impaired in their proliferation and accumulate in $\mathrm{G}_{1}$ phase of the cell cycle. (A) Analysis of TAF 30 , TBP, TAF 55 and $\mathrm{TAF}_{\mathrm{II}} 100$ protein levels in HeLa, F9 WT and $\mathrm{TAF}_{\mathrm{II}} 30^{-\mathrm{La} /-\mathrm{Lb}}: \mathrm{R}$ cells grown in the presence $(+)$ or absence $(-)$ of Dox. Whole-cell extracts were prepared from the various cell lines as indicated, and $25 \mu \mathrm{g}$ of each protein extract was loaded on to a $10 \%$ gel and analysed by Western blotting using mAbs raised against TBP, $\mathrm{hTAF}_{\mathrm{II}} 55$ and $\mathrm{TAF}_{\mathrm{II}} 100$ (see Wieczorek et al., 1998). (B) $10^{4}$ cells were plated on day zero in the presence (+Dox) or absence (-Dox) of Dox and counted for 6 days. The number of cells grown in the presence (black columns) and absence (white columns) of Dox are indicated. (C) $\mathrm{TAF}_{\mathrm{II}} 30^{-\mathrm{La} /-\mathrm{Lb}}: \mathrm{R}$ cells were grown in the presence (+Dox) or absence (-Dox) of Dox for 2 and 5 days as indicated, as subconfluent cultures. Cells were fixed, stained with PI and analysed by FACS. The $x$-axis indicates the DNA content and the $y$-axis the cell number. For each histogram 20000 particles have been gated. For each +Dox and -Dox sample, the living cells ( $x$-axis is a linear scale) and all the particles ( $x$-axis is a log scale) were gated in the right and left panels, respectively. The percentage of cells in $\mathrm{G}_{1} / \mathrm{G}_{0}, \mathrm{~S}$ and $\mathrm{G}_{2} / \mathrm{M}$ are indicated (accurate to within $\pm 5 \%$ ). M1 represents the sub-2N size DNA-containing particles.

propidium iodide (PI). The proportion of pre-apoptotic particles was similar when $\mathrm{TAF}_{\mathrm{II}} 30^{-\mathrm{La} /-\mathrm{Lb}}: \mathrm{R}$ cells were grown for 2 days in the absence or presence of Dox (Figure 6A, 4 and 10\% annexin V+, PI- cells, respectively). However, 5 days after Dox withdrawal $>60 \%$ of the $\mathrm{TAF}_{\mathrm{II}} 30^{-\mathrm{La} /-\mathrm{Lb}}: \mathrm{R}$ cells were pre-apoptotic, whereas when the cells were grown in the presence of Dox for 5 days, only $16 \%$ were pre-apoptotic (Figure 6A). Taken together, these results demonstrate that F9 cells undergo apoptosis in the absence of $\mathrm{TAF}_{\mathrm{II}} 30$ expression.

\section{Parietal, but not primitive endodermal differentiation is impaired in $\mathrm{TAF}_{\| / 30}$-null cells}

To analyse the function of $\mathrm{TAF}_{\mathrm{II}} 30$ during RA-induced differentiation, $\mathrm{TAF}_{\mathrm{II}} 30^{-\mathrm{La} /-\mathrm{Lb}}: \mathrm{R}$ cells were grown for $60 \mathrm{~h}$ as monolayers in the presence or absence of Dox, and then grown further in the presence or absence of $1 \mu \mathrm{M}$ RA. As for WT cells, RA induced a severe decrease of the proliferation rate of $\mathrm{TAF}_{\mathrm{II}} 30^{-\mathrm{La} /-\mathrm{Lb}}: \mathrm{R}$ cells expressing hTAF $_{\text {II }} 30$ (+Dox) (Figure 6D and data not shown) and induced a primitive endodermal-like morphological 


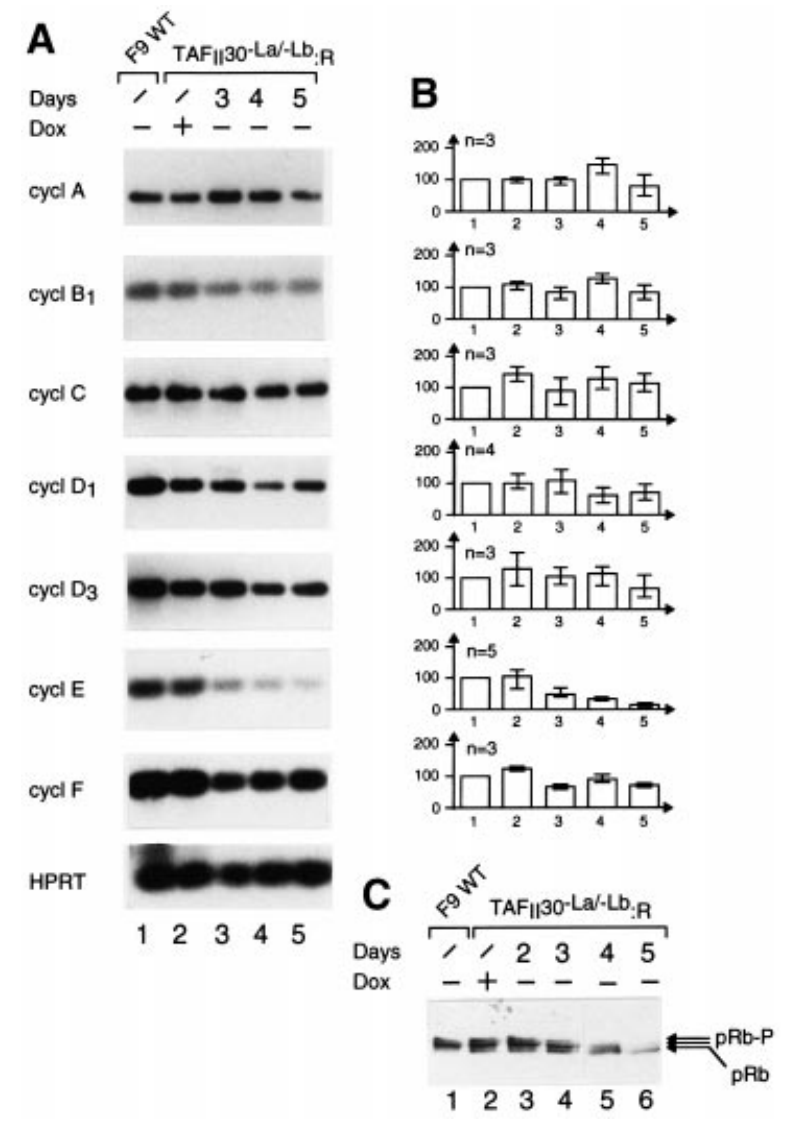

Fig. 5. Cyclin E expression and phosphorylation of $\mathrm{pRb}$ is impaired in $\mathrm{TAF}_{\mathrm{II}} 30$-null cells. (A) Total cytoplasmic RNA from WT or $\mathrm{TAF}_{\mathrm{II}} 30^{-\mathrm{La} /-\mathrm{Lb}}: \mathrm{R}$ cells, grown either in the presence of Dox $(+)$ or for the indicated number of days without Dox (-), was subjected to RT-PCR analysis for the following cyclin genes (number of PCR cycles in parentheses): cyclin A (25), cyclin B1 (15), cyclin C (20), cyclin D1 (18), cyclin D3 (15), cyclin E (15), and cyclin F (18). The hypoxanthine phosphoribonucleotide transferase (HPRT) gene (10 PCR cycles) was used as an internal control. (B) RT-PCR analysis of the cyclin genes was performed as in (A) for at least three independent experiments [the number of experiments $(n)$ is indicated]. The mRNA levels of the different cyclin genes are expressed relative to the amount present in the WT cells, which was taken as $100 \%$. The error bars represent the minimal and maximal values obtained. The number under each bar corresponds to the same lane in (A). (C) Whole-cell extracts from WT or $\mathrm{TAF}_{\mathrm{II}} 30^{-\mathrm{La} /-\mathrm{Lb}}: \mathrm{R}$ cells, grown either in the presence of $(+)$ or for the indicated days without $(-)$ Dox, were subjected to Western blot analysis using the anti-pRb G3-245 mAb (PharMingen). The hypophosphorylated $(\mathrm{pRb})$ and the

hyperphosphorylated (pRb-P) forms of $\mathrm{pRb}$ are indicated.

differentiation (Figure 7). Whereas undifferentiated $\mathrm{TAF}_{\mathrm{II}} 30$-null cells died within 5-7 days of Dox withdrawal [Figures 4B, 6D and 7A (c); data not shown], surprisingly the RA treatment of $\mathrm{TAF}_{\mathrm{II}} 30$-null cells prevented rapid cell death and induced a primitive endodermal morphological differentiation, similar to that observed with $\mathrm{TAF}_{\mathrm{II}} 30$ containing cells [Figure 7A (e) and (f)]. Thus, the genes which are required for this differentiation pathway are expressed in the $\mathrm{TAF}_{\mathrm{II}} 30$-null cells. Furthermore, several RA-inducible genes, i.e. RAR $\beta 2$, Hox-1, Stra4 and Stra 8 (Chiba et al., 1997b) were similarly induced in $\mathrm{TAF}_{\mathrm{II}} 30$ null and WT cells after 2 days of RA treatment (data not shown). Moreover, the RA-treated $\mathrm{TAF}_{\mathrm{II}} 30$-null cells survived for $>10$ days (Figure 6D). Interestingly, in the presence of $\mathrm{RA}$ the $\mathrm{TAF}_{\mathrm{II}} 30^{-\mathrm{La} /-\mathrm{Lb}}: \mathrm{R}$ cells arrested with a similar time course when grown in the absence or presence of Dox (Figure 6D). The RA treatment of $\mathrm{TAF}_{\mathrm{II}} 30^{-\mathrm{La} / \mathrm{Lb}}: \mathrm{R}$ cells grown in the presence of Dox resulted in a moderate increase (from 16 to $22 \%$ ) in preapoptotic cells (compare + Dox 5 days in Figure 6A with B), in agreement with previous studies performed on WT F9 cells (Clifford et al., 1996). Note that this low level of apoptosis could not be visualized in the DNA ladder assay used in this study (Figure 6C and data not shown). In contrast, the RA treatment of the $\mathrm{TAF}_{\mathrm{II}} 30^{-\mathrm{La} / \mathrm{Lb}}: \mathrm{R}$ cells in the absence of Dox resulted in a strong reduction in pre-apoptotic cells (from 61 to 20\%) as detected by fluorescence-activated cell sorting (FACS) analysis (compare -Dox 5 days in Figure 6A with B) or by the absence of fragmented apoptotic DNA 'ladder' (Figure 6C, compare lanes 17 with 18,21 with 22 , and 25 with 26).

To induce parietal endodermal differentiation, WT and $\mathrm{TAF}_{\mathrm{II}} 30^{-\mathrm{La} / \mathrm{Lb}}: \mathrm{R}$ cells were grown in monolayer culture in the absence or presence of Dox and treated with $1 \mu \mathrm{M}$ RA and $250 \mu \mathrm{M} \mathrm{bt}{ }_{2} \mathrm{cAMP}$. The morphological changes which normally accompany RA + cAMP-induced differentiation of WT cells were observed in $\mathrm{TAF}_{\mathrm{II}} 30^{-\mathrm{La} / \mathrm{Lb}}: \mathrm{R}$ cells expressing $\mathrm{hTAF}_{\mathrm{II}} 30$ [Figure $7 \mathrm{~A}(\mathrm{~h})$ ]. In contrast, $\mathrm{TAF}_{\mathrm{II}} 30$-null cells (-Dox), although they differentiated into primitive endoderm-like cells, were strongly impaired in parietal endodermal differentiation. The parietal differentiation of WT and mutant cells was also investigated by determining the expression of the thrombomodulin (TM) gene, a marker of parietal endodermal differentiation (Niforas et al., 1996; C.Rochette-Egly, personal communication). As expected, after 10 days of RA+cAMP treatment, TM was strongly stimulated in WT and mutant cells expressing hTAF $_{\text {II }} 30$ ( + Dox) ( $>90$-fold, Figure 7B). In contrast, in the $\mathrm{TAF}_{\mathrm{II}} 30$-null cells (-Dox) the induction of TM was very low ( $<6$-fold) and the levels of TM were at least five times lower than in the WT or $\mathrm{hTAF}_{\mathrm{II}} 30$ expressing (+Dox) cells (Figure 7B). Taken together, these results indicate that $\mathrm{TAF}_{\mathrm{II}} 30$-null cells are strongly impaired in parietal, but not primitive endodermal differentiation.

\section{Discussion}

\section{TAF}

In this study, we performed conditional disruption of the $T A F_{I I} 30$ gene in F9 murine embryonal carcinoma cells, using a Cre/LoxP strategy. No F9 cell clone disrupted for the two alleles could be isolated, indicating that undifferentiated $\mathrm{TAF}_{\mathrm{II}} 30$-null $\mathrm{F} 9$ cells are impaired in their proliferation. This was confirmed by a study of the genotype of a $\mathrm{TAF}_{\mathrm{II}} 30^{+/-}\left[\mathrm{TAF}_{\mathrm{II}} 30^{-\mathrm{La} /(\mathrm{L} / \mathrm{L}) \mathrm{b}}\right] \mathrm{F} 9$ cell population after Cre-mediated disruption of the second allele. Although $\mathrm{TAF}_{\mathrm{II}} 30^{--}\left(\mathrm{TAF}_{\mathrm{II}} 30^{-\mathrm{La} /-\mathrm{Lb}}\right)$ cells could be detected during the 5 days which followed Cre recombinase transfection, their number did not increase with time and they eventually disappeared after a week, whereas $\mathrm{TAF}_{\mathrm{II}} 30^{+/-}$cells proliferated normally. The Cre-mediated disruption of the targeted alleles encodes a truncated protein lacking the C-terminal evolutionary conserved domain. Importantly, neither the truncated mRNA nor the protein could be detected in heterozygous cells $\left(\mathrm{TAF}_{\mathrm{II}} 30^{+-}\right)$or in rescue cells in which both alleles are 
A
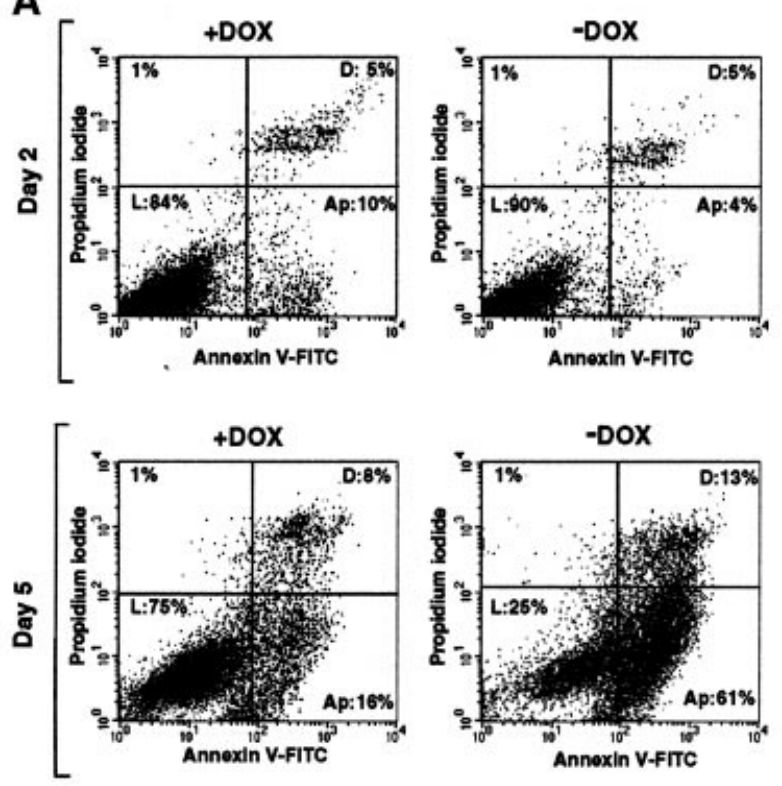

C
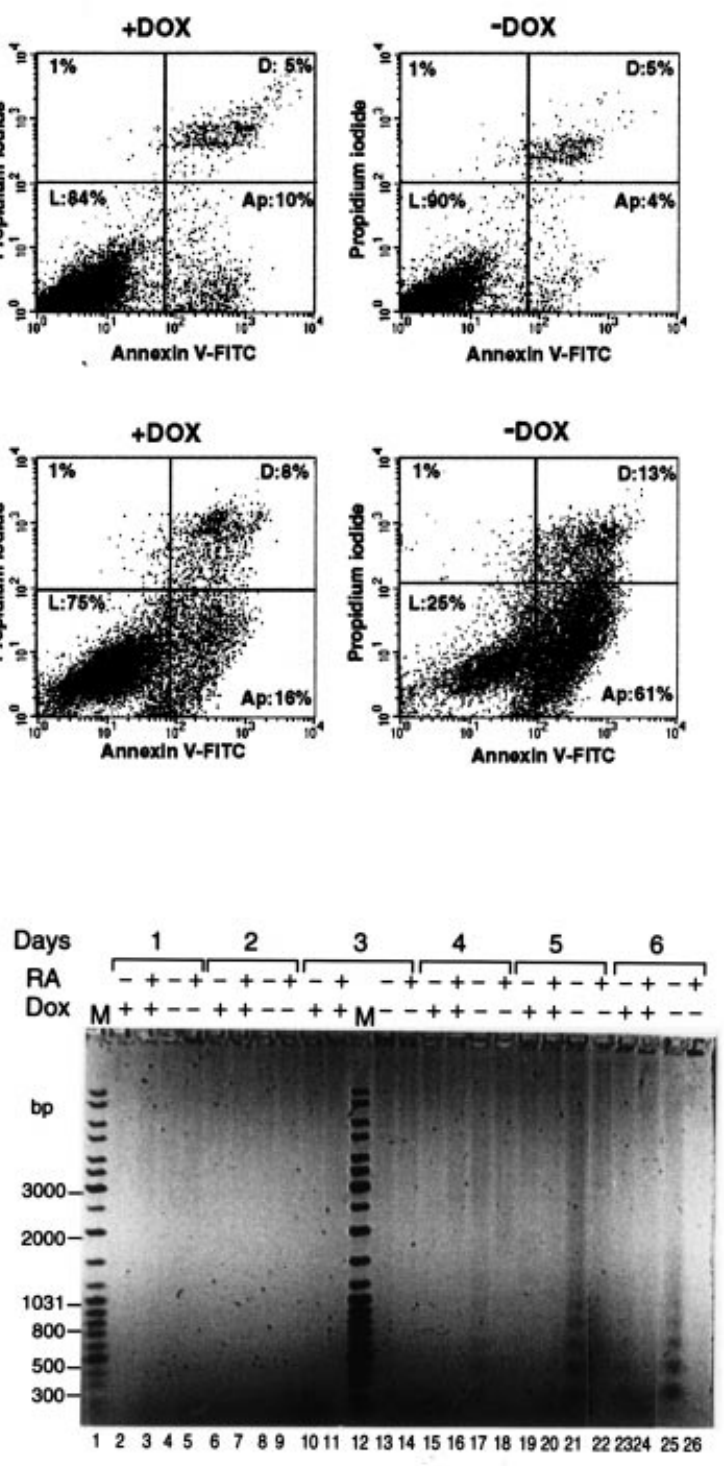

B

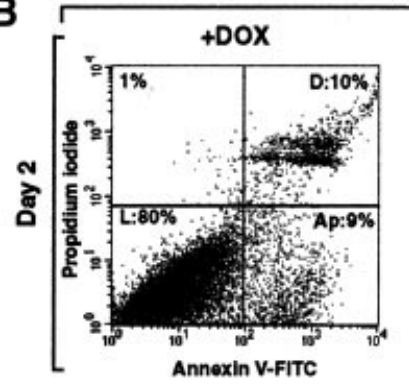

+RA
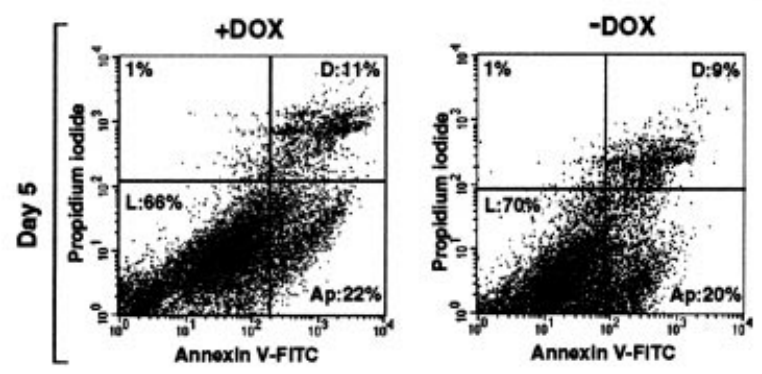

D

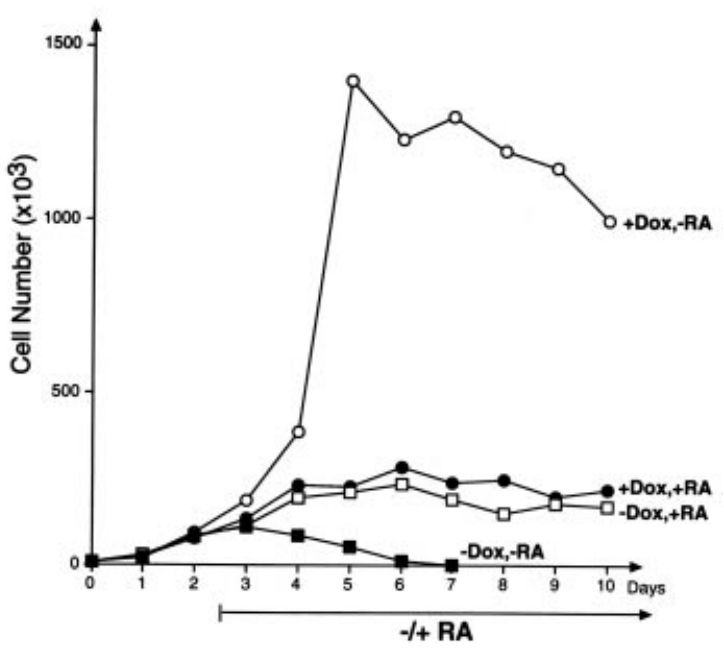

Fig. 6. $\mathrm{TAF}_{\mathrm{II}} 30$-null cells die by apoptosis but $\mathrm{RA}$ strongly reduces the rate of apoptosis of the $\mathrm{TAF}_{\mathrm{II}} 30$-null cells. TAF $30^{-\mathrm{La} /-\mathrm{Lb}}: \mathrm{R}$ cells, grown in the presence (+Dox) or absence (-Dox) of Dox, and either in the absence (A) or presence (B) of $1 \mu \mathrm{M}$ RA for the indicated number of days, were labelled with annexin V-fluorescein isothiocyanate (annexin V-FITC) and PI, and subjected to FACS. The results in (A) and (B) are represented as dual parameter scatter plots. The values indicated for the percentage of living (L; annexin V-, PI-), early apoptotic (Ap; annexin V+, PI-) and dead $(\mathrm{D}$; annexin $\mathrm{V}+, \mathrm{PI}+)$ cells are accurate to within $\pm 5 \%$. (C) $\mathrm{TAF}_{\mathrm{II}} 30^{-\mathrm{La} /-\mathrm{Lb}}: \mathrm{R}$ cells were grown in the presence (+Dox) or absence (-Dox) of Dox, and in the presence (+RA) or absence (-RA) of retinoic acid, as indicated. Low mol. wt DNA (see Materials and methods) was electrophoresed in a $1.2 \%$ agarose gel, followed by ethidium bromide staining. The DNA marker (M) size is expressed in bp. (D) $10^{4} \mathrm{TAF}_{\mathrm{II}} 30^{-\mathrm{La} /-\mathrm{Lb}}: \mathrm{R}^{\mathrm{cell}} \mathrm{s}$ were plated on day zero. Cells were grown in the presence (+Dox) or absence (-Dox) of Dox and $1 \mu \mathrm{M}$ RA (added $60 \mathrm{~h}$ after plating) as indicated. Cells were counted each day for 10 days.

inactivated. Therefore, inactivation of both $T A F_{I I} 30$ alleles results in $\mathrm{TAF}_{\mathrm{II}} 30$-null $\mathrm{F} 9$ cells.

\section{Human $T A F_{\mid l} 30$ can functionally replace its mouse counterpart}

To analyse further the function of $\mathrm{TAF}_{\mathrm{II}} 30$ in $\mathrm{F} 9$ cells, we have generated an F9 cell line expressing the human $\mathrm{TAF}_{\mathrm{II}} 30$ protein in a conditional manner, in which both $T A F_{I I} 30$ alleles have been inactivated $\left(\mathrm{TAF}_{\mathrm{II}} 30^{-\mathrm{La} /-\mathrm{Lb}}: \mathrm{R}\right.$ cells). $\mathrm{TAF}_{\mathrm{II}} 30^{-\mathrm{La} / \mathrm{Lb}}: \mathrm{R}$ cells expressing $\mathrm{hTAF}_{\mathrm{II}} 30$ are viable, in contrast to $\mathrm{TAF}_{\mathrm{II}} 30$-null cells, showing that $\mathrm{hTAF}_{\mathrm{II}} 30$ can functionally replace $\mathrm{mTAF}_{\mathrm{II}} 30$ in $\mathrm{F} 9$ cells and suggesting that $\mathrm{hTAF}_{\mathrm{II}} 30$ can enter into the different murine $\mathrm{TAF}_{\mathrm{II}} 30$-containing complexes such as TFIID, TFTC and PCAF/GCN5 complexes. This is in good agreement with the high homology between the mouse and human proteins. However, some differences between $\mathrm{TAF}_{\mathrm{II}} 30^{-\mathrm{La} /-\mathrm{Lb}}: \mathrm{R}$ cells expressing $\mathrm{hTAF}_{\mathrm{II}} 30$ and WT cells were observed. For example, their RA-induced morphological primitive endodermal differentiation is similar, although not identical, and parietal endodermal differentiation of the rescue cells is delayed by $48-56 \mathrm{~h}$ (data not shown). This partial rescue might reflect the amino acid differences between the $\mathrm{N}$-terminal region of the mouse 


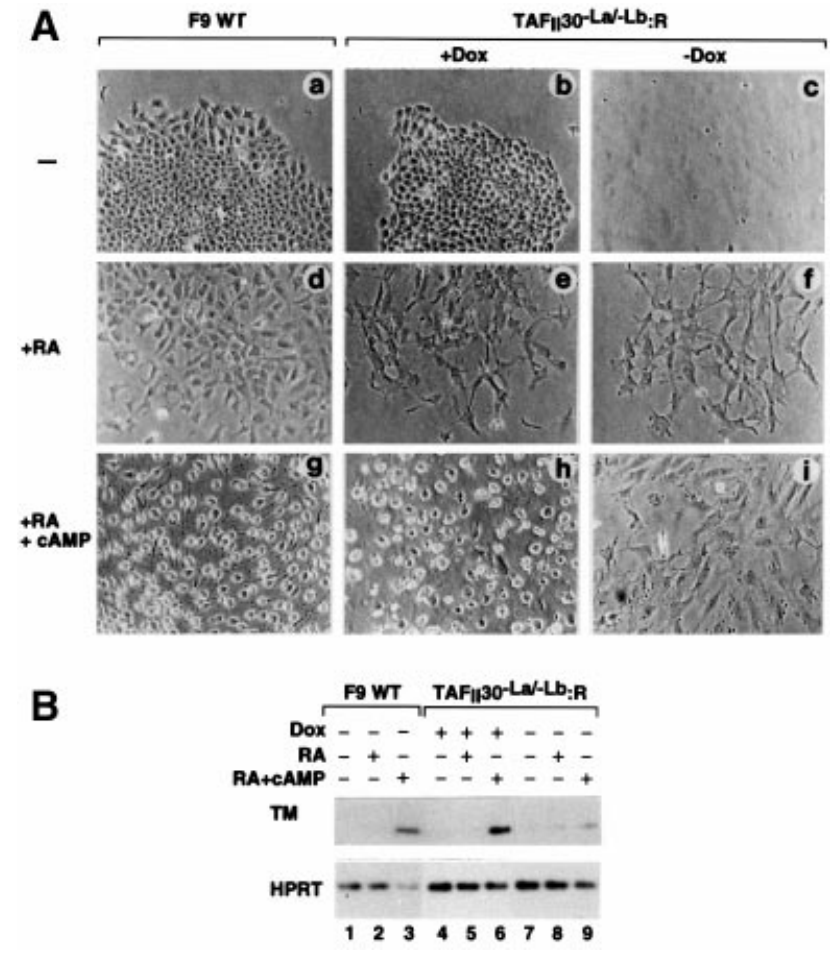

Fig. 7. Parietal but not primitive endodermal differentiation is impaired in $\mathrm{TAF}_{\mathrm{II}}$ 30-null cells. (A) WT [(a), (d) and (g)], and $\mathrm{TAF}_{\mathrm{II}} 30^{-\mathrm{La} /-\mathrm{Lb}}: \mathrm{R}$ cultured in the presence [+Dox; (b), (e) and (h)] or absence [-Dox; (c), (f) and (i)] of Dox were treated $60 \mathrm{~h}$ after plating with either control vehicle [(a), (b) and (c)], $1 \mu \mathrm{M}$ RA [(d), (e) and (f)] or $1 \mu \mathrm{M}$ RA $+250 \mu \mathrm{M} \mathrm{bt}_{2} \mathrm{cAMP}[(\mathrm{g})$, (h) and (i)]. Cells were photographed $[8,10$ and 12 days following the plating for $(\mathrm{a}-\mathrm{f}),(\mathrm{g})$ and $(\mathrm{h}-\mathrm{i})$, respectively] under a phase-contrast microscope at $125 \times$ magnification. (B) Cytoplasmic RNA from WT or $\mathrm{TAF}_{\mathrm{II}} 30^{-\mathrm{La} /-\mathrm{Lb}}: \mathrm{R}$ cells (grown either in the presence or absence of Dox) and treated with RA alone or RA + cAMP (as indicated) for 10 days, was subjected to RT-PCR analysis to test the expression of the parietal marker gene TM. The HPRT gene was used as an internal control.

and the human protein and/or the absence of regulation of the transgene expression.

\section{$T A F_{\mid l} 30$ is required for $G_{1} / S$ progression of the cell cycle and cyclin $E$ expression}

The conditional expression of $\mathrm{hTAF}_{\mathrm{II}} 30$ in $\mathrm{TAF}_{\mathrm{II}} 30^{-/-}$cells allowed us to study its role in the cell cycle regulation. FACS analysis showed that $\mathrm{TAF}_{\mathrm{II}} 30$-null cells accumulate in $\mathrm{G}_{1} / \mathrm{G}_{0}$ phase. Molecular analyses revealed that cyclin $\mathrm{E}$ expression is down-regulated after suppression of $\mathrm{TAF}_{\mathrm{II}} 30$ expression, while expression of cyclin-dependent kinase inhibitor p21 is enhanced (data not shown). Consistent with the decreased cyclin E and increased p21 expression, we found that phosphorylation of $\mathrm{pRb}$ is decreased in $\mathrm{TAF}_{\mathrm{II}} 30$ lacking cells. These changes are all possible causes of the $\mathrm{G}_{1}$ cell cycle arrest phenotype of the $\mathrm{TAF}_{\mathrm{II}} 30$ lacking cells. Taken together, these results suggest that $\mathrm{TAF}_{\mathrm{II}} 30$ may regulate cyclin E expression and that only certain genes are regulated (directly or indirectly) by $\mathrm{TAF}_{\mathrm{II}} 30$.

Interestingly, growth arrest of $y T A F_{I I} 90$ and $y T A F_{I I} 150$ (Tsm1) mutant yeast strains occurs at the $\mathrm{G}_{2} / \mathrm{M}$ boundary of the cell cycle, whereas $y T A F_{I I} 145$ mutant strains arrest in $\mathrm{G}_{1}$ phase (Apone et al., 1996; Walker et al., 1996). $\mathrm{yTAF}_{\mathrm{II}} 145$ has been shown to be required for transcription of $\mathrm{G}_{1}$ cyclins and certain B-type cyclin genes (Walker et al., 1997). Furthermore, a hamster cell line containing a temperature-sensitive mutation in $\mathrm{TAF}_{\mathrm{II}} 250$ undergoes $\mathrm{G}_{1}$ arrest upon shifting to the restrictive temperature (Sekiguchi et al., 1991), resulting in reduced transcription of $\mathrm{G}_{1}$ cyclin genes such as cyclin A and D1 (Wang and Tjian, 1994; Suzuki-Yagawa et al., 1997; Wang et al., 1997). Thus, different $\mathrm{TAF}_{\mathrm{II}} \mathrm{S}$ may specifically regulate distinct cyclin genes to control cell proliferation.

\section{RA prevents cell death of TAF induces primitive, but not parietal endodermal differentiation}

Our results indicate that cells lacking $\mathrm{TAF}_{\mathrm{II}} 30$ are not simply arrested in $\mathrm{G}_{1} / \mathrm{G}_{0}$ phase of the cell cycle, but undergo apoptosis (Figures 4C, 6A and C). The analysis of the expression of 80 genes (on a mouse cDNA expression array) involved in the regulation of apoptosis, revealed that the mRNA levels of 14 genes were up-regulated (i.e. encoding caspase 3, 6 and 11, BAD and BID) and five genes were down-regulated (encoding i.e. the p55 cell division control protein and the glutathione $S$-tranferase $\mathrm{Mu} 1$ protein) in $\mathrm{TAF}_{\mathrm{II}} 30$-null cells when compared with cells expressing $\mathrm{hTAF}_{\mathrm{II}} 30$ (data not shown). Whether $\mathrm{TAF}_{\mathrm{II}} 30$ is directly or indirectly involved in the regulation of these genes is unknown. The lack of $\mathrm{TAF}_{\mathrm{II}} 30$ may induce apoptosis indirectly by deregulating distinct cell cycle check-points, i.e. pRb and/or E2F activities. A recent study has suggested that another 'specific' $\mathrm{TAF}_{\mathrm{II}}$, $\mathrm{hTAF}_{\mathrm{II}} 105$, is involved in activation of anti-apoptotic genes by serving as a co-activator for NF- $\mathrm{KB}$, a factor known to protect cells from apoptotic stimuli (Yamit-Hezi and Dikstein, 1998). It is therefore conceivable that $\mathrm{TAF}_{\mathrm{II}} \mathrm{S}$ may regulate anti-apoptotic events through different pathways.

Interestingly, after RA-treatment, $\mathrm{TAF}_{\mathrm{II}} 30$-null cells did not die, but differentiated into primitive endodermal-like cells, and arrested with a similar time course to the RAtreated WT F9 cells (Figure 6D). Therefore, in contrast to WT cells (where RA not only induces differentiation, but also antiproliferation and apoptosis), RA-induced differentiation prevents $\mathrm{TAF}_{\mathrm{II}} 30$-null cell death by strongly reducing apoptosis. These data suggest that when the cells are programmed to proliferate, $\mathrm{a}_{1}$ check-point, where the $\mathrm{TAF}_{\mathrm{II}} 30$ function is indispensable, does not function properly and apoptosis is triggered. On the other hand, when cells are programmed to differentiate by RA, the $G_{1}$ check-point is not used since the cells enter $G_{0}$, and thus $\mathrm{TAF}_{\mathrm{II}} 30$-null cells differentiate into primitive endodermal cells and survive. Strikingly however, the genes that are needed to trigger the morphological changes leading to primitive endodermal differentiation, are correctly expressed in $\mathrm{TAF}_{\mathrm{II}} 30$-null cells. In contrast, parietal endodermal differentiation is strongly impaired in $\mathrm{TAF}_{\mathrm{II}} 30$-null cells. Parietal endodermal differentiation is apparently achieved in two steps, an initial RA-induced differentiation into primitive endoderm, followed by a cAMP-induced differentiation switch from primitive to parietal endoderm (Strickland et al., 1980). Thus, $\mathrm{TAF}_{\mathrm{II}} 30$ may be involved in the regulation of certain cAMPinduced genes. In any event, our results indicate that $\mathrm{TAF}_{\mathrm{II}} 30$ is not needed for the transcription of genes required for the differentiation pathways leading to the primitive endodermal differentiation of $\mathrm{F} 9$ cells and for 
their survival in the $\mathrm{G}_{0}$ state. Interestingly, several RAresponsive genes can be activated in $\mathrm{TAF}_{\mathrm{II}} 30$-null cells to similar levels to those in WT cells (data not shown), indicating that $\mathrm{TAF}_{\mathrm{II}} 30$-containing complexes are not absolutely required for transcriptional activation by RAR/ RXR heterodimers. In conclusion, we have identified a cellular context in which mammalian cells can survive in the absence of $\operatorname{TAF}_{\mathrm{II}} 30$, indicating that all genes necessary for primitive differentiation and survival of F9 cells can be activated without $\mathrm{TAF}_{\mathrm{II}} 30$. In contrast to the yeast $\mathrm{TAF}_{\mathrm{II}}$ knock-out experiments (Moqtaderi et al., 1996a; Walker et al., 1996), the expression of different $\mathrm{mTAF}_{\mathrm{II}} \mathrm{S}$ and mTBP was not affected in $\mathrm{TAF}_{\mathrm{II}} 30$-null cells (Figure 4B) further suggesting that the TFIID, TFTC and PCAF/GCN5 complexes may function without $\mathrm{TAF}_{\mathrm{II}} 30$.

Our results demonstrate that mammalian $\mathrm{TAF}_{\mathrm{II}} \mathrm{S}$ are not generally required for activator-dependent transcription, but are essential for the transcription of specific genes. Further in vitro experiments will be needed to understand the exact molecular mechanisms by which $\mathrm{TAF}_{\mathrm{II}} 30$ in the different $\mathrm{TAF}_{\mathrm{II}} 30$-containing complexes, such as TFIID, TFTC and PCAF/GCN5, modulates the transcription of a subset of genes.

\section{Materials and methods}

\section{Cloning of the mouse $T_{A F} 30$ gene and determination of exon-intron boundaries}

A mouse embryonic stem (ES) cell genomic library constructed in $\lambda$ GEM12 phage was screened with a 300 bp human $\operatorname{TAF}_{\text {II }} 30$ cDNA probe (from position 355 to 654; Jacq et al., 1994). A $16 \mathrm{~kb}$ DNA fragment containing the entire mouse $T A F_{I I} 30$ gene and its flanking sequences was subcloned in pBluescript II SK + (pBSK, Stratagene) and mapped with restriction enzymes (Figure 1). The exon-intron boundaries of the mouse $(m) T A F_{I I} 30$ gene were determined by DNA sequencing.

\section{Targeting of the $\mathrm{TAF}_{\| / 30}$ gene in F9 cells}

The targeting vectors $\mathrm{pTAF}_{\mathrm{II}} 30^{(\mathrm{L}: \mathrm{LNL}) \mathrm{a}}$ and $\mathrm{pTAF}_{\mathrm{II}} 30^{(\mathrm{L}: \mathrm{LNL}) \mathrm{b}}$ were constructed as follows. The $3.2 \mathrm{~kb} B a m \mathrm{HI}-E c o \mathrm{RI}$ restriction fragment, containing exons 1,2 and 3 of the $m T A F_{I I} 30$ gene (Figure 1A), was subcloned into the corresponding sites of pBEX, resulting in pBEXTAF1-3. pBEX is a pBSK derived vector containing a new polylinker (BamHI, EcoRI and XhoI), obtained by cloning the oligonucleotides 5'-GGTACCGTGGAATTCAGCTCGAGAGTAC-3' and 5'-TCTCGAGCTGAATTCCACGGTACCAGCT-3' into the $\mathrm{SacI}$ and $\mathrm{KpnI}$ sites of pBSK. A SalI site was introduced between exons 1 and 2, and a NotI site between exons 2 and 3 by site directed mutagenesis of pBEXTAF1-3 with the oligonucleotides 5'-CCCCGGCACCTAGTCGACGATGCCCTCCTCCTCCCT-3' and 5'-GGCAGAGGCAGGCGGCCGCTGAGTTCAAAGCCAG-3', respectively, resulting in pBEX-TAFSN. The oligonucleotides 5'-TCGACATAACTTCGTATAATGTATGCTATACGAAGTTATGGTACC-3' and 5'-TCGAGGTACCATAACTTCGTATAGCATACATTATACGAAGTTATG-3', containing a loxP site (labelled as ${ }^{\mathrm{La}}$ or ${ }^{\mathrm{Lb}}$ in the following constructions, depending on their orientation), were cloned into the SalI site of pBEX-TAFSN, resulting in pBEX-TAF ${ }^{\mathrm{L}} \mathrm{N}$ and $\mathrm{pBEX}-\mathrm{TAF}^{\mathrm{Lb}} \mathrm{N}$. To clone the floxed tk-Neo cassette (Metzger et al., 1995) into the NotI site of pBEX-TAF ${ }^{\mathrm{La}} \mathrm{N}$ and $\mathrm{pBEX}-\mathrm{TAF}^{\mathrm{Lb}} \mathrm{N}$ vectors, a polylinker containing the following restriction sites (NotI, ClaI, BglII, XbaI, SacI and NotI; 5'-GCGGCCGCTAAATCGATTCGAGATCTCAAGTCTAGAGACGAGCTCTAAGCGGCCGCGTAC-3' ) was cloned in the $S a c \mathrm{I}$ and $K p n \mathrm{I}$ sites of pBSK, resulting in pBSK-NBXN. The $3.2 \mathrm{~kb} \mathrm{BamHI-XbaI}$ fragment containing the floxed tk-Neo cassette, isolated from pHR56 (Metzger et al., 1995), was cloned into the corresponding sites of pBSK-NBXN, resulting in $\mathrm{pN}^{\mathrm{LNL}}-\mathrm{XN}$. The $3 \mathrm{~kb}$ NotI fragment containing the floxed tk-Neo cassette excised from this vector and introduced into the NotI sites of pBEX-TAF ${ }^{\mathrm{La}} \mathrm{N}$ and $\mathrm{pBEX}-\mathrm{TAF}^{\mathrm{Lb}} \mathrm{N}$ vectors, resulted in $\mathrm{pBEX}-\mathrm{TAF}_{\mathrm{II}} 30^{(\mathrm{L}: \mathrm{LNL}) \mathrm{a}}$ and

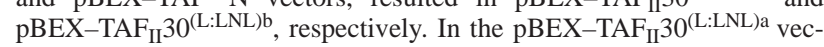
tor the three loxP sites are in the (a) orientation and in the pBEX$\mathrm{TAF}_{\mathrm{II}} 30^{(\mathrm{L}: \mathrm{LNL}) \mathrm{b}}$ vector the three loxP sites are in the opposite, (b) orientation. To obtain the final targeting vectors, the $6.7 \mathrm{~kb} E c o$ RI-XhoI
DNA fragment containing $m T A F_{I I} 30$ exons 4 and 5 and its $3^{\prime}$ flanking sequences, was inserted into the $\mathrm{pBEX}-\mathrm{TAF}_{\mathrm{II}} 30^{(\mathrm{L}: \mathrm{LN}) \mathrm{La}}$ and $\mathrm{pBEX}-$ $\mathrm{TAF}_{\mathrm{II}} 30^{(\mathrm{L}: \mathrm{LNL}) \mathrm{b}}$, resulting in the targeting vectors $\mathrm{pTAF}_{\mathrm{II}} 30^{\mathrm{L}: \mathrm{LNL}) \mathrm{a}}$ and $\mathrm{pTAF}_{\mathrm{II}} 30^{(\mathrm{L}: \mathrm{LNL}) \mathrm{b}}$ (Figure 1). The Cre expression vector pSG-Cre was obtained by cloning a PCR-amplified Cre gene (Metzger et al., 1995) into the EcoRI-BgIII sites of pSG5.

F9 cells were electroporated with $5 \mu \mathrm{g}$ of the $13.8 \mathrm{~kb} \mathrm{BamHI-XhoI}$ fragment, isolated either from $\mathrm{pTAF}_{\mathrm{II}} 30^{(\mathrm{L}: \mathrm{LNL}) \mathrm{a}}$ or $\mathrm{pTAF}_{\mathrm{II}} 30^{(\mathrm{L}: \mathrm{LNL}) \mathrm{b}}$ vectors (Figure 1), or with $5 \mu \mathrm{g}$ of the $\mathrm{pSG}-\mathrm{Cre}$ expression vector (Clifford et al., 1996). The selection of neomycin-resistant clones, Cre recombinase mediated excision and Southern blot analysis were performed as described (Metzger et al., 1995). The 5' probe corresponds to a $0.8 \mathrm{~kb} E c o \mathrm{RV}-K p n \mathrm{I}$ genomic fragment, located outside the genomic sequences present in the targeting vector (Figure 1A). The primers used for the identification of the genotypes (Figures $2 \mathrm{C}$ and $3 \mathrm{C}$ ) and their locations were as follows: SG12 (5'-CTGCCCACTAGCACGGCC-3') located in the first exon, SE89 (5'-CAGTCTAACCTGCTCCGAG-3') located between exons 3 and 4, and WY60 ( $5^{\prime}$-CGCTTAGAGCTCGTCTCTAG-3') specific to the junction between the Loxb site and intron 2 (Figures 1 and 3).

\section{A Dox-inducible hTAF II $^{30}$ expression system in F9 $T A F_{\| /} 30^{-L a /(L: L) / b}$ cells}

The expression vector pDG1-rtTA, in which the expression of the rtTA (Gossen et al., 1995) is under the control of the PGK promoter, was constructed by inserting the 1044-bp EcoRI-BamHI fragment isolated from pUHD172-1Neo (Gossen et al., 1995) into the corresponding sites of the pDG1 expression vector. An EcoRI-BgIII human $T A F_{I I} 30$ cDNA fragment was excised from pXJ-TAF30 (Jacq et al., 1994) and cloned into the EcoRI-BamHI sites of the pUHD10-3 vector (Gossen and Bujard, 1992), resulting in the expression vector pUHD10-TAF30 in which the expression of $\mathrm{hTAF}_{\mathrm{II}} 30$ is under the control of the tet-operator. The $\mathrm{TAF}_{\mathrm{II}} 30^{-\mathrm{La} /(\mathrm{L}: \mathrm{L}) \mathrm{b}} \mathrm{F}$ 9 cells were co-electroporated with $5 \mu \mathrm{g}$ of pDG1-rtTA and linearized by AatII and with $0.5 \mu \mathrm{g}$ of XhoI-digested pPGK-hygro vector (te Riele et al., 1990). After hygromycin selection, rtTA positive clones were selected by genomic PCR using the primers QY74 (5'-CACGCTTCAAAAGCGCACGT-3') and WK31 (5'-CAATACAGTGTAGGCTGCTGCTC-3'), and by Western blotting analysis using three anti-VP16 monoclonal antibodies (2GV4, 5GV2 and 5GV7; White et al., 1992). A rtTA positive $\mathrm{TAF}_{\mathrm{II}} 30^{-\mathrm{La} /(\mathrm{L}: \mathrm{L}) \mathrm{b}}$ cell line was coelectroporated with $5 \mu \mathrm{g}$ of the $2 \mathrm{~kb}$ AatII-HindIII DNA fragment isolated from pUHD10-TAFII30 and with $0.5 \mu \mathrm{g}$ of the neomycinresistance cassette (a $1.6 \mathrm{~kb} B g l$ II DNA fragment isolated from the vector $\mathrm{pKJ}-1 \mathrm{~B}$; pKJ-1B was obtained by cloning the oligonucleotide 5'-AATTAGATCT-3' into the EcoRI site of pKJ1; McBurney et al., 1991). After neomycin selection, cells were treated with $1 \mu \mathrm{g} / \mathrm{ml}$ Dox for 3 days, and $\mathrm{hTAF}_{\mathrm{II}} 30$ positive clones were selected by Western blot analysis using the human $\mathrm{TAF}_{\mathrm{II}} 30$-specific antibody $2 \mathrm{~F} 4$ (Jacq et al., 1994).

\section{Western blot analysis}

Cells resuspended in $20 \mathrm{mM}$ Tris- $\mathrm{HCl} \mathrm{pH} \mathrm{7.5,} 2 \mathrm{mM}$ DTT, 20\% glycerol, $0.4 \mathrm{M} \mathrm{KCl}, 1 \mathrm{mM}$ PMSF and protease inhibitor cocktail $(2.5 \mu \mathrm{g} / \mathrm{ml}$ of leupeptin, pepstatin, chymostatin, antipain and aprotinin), were lysed by three cycles of freeze-thaw and cell debris was eliminated by centrifugation. Proteins were loaded on a $10 \%$ SDS-polyacrylamide gel, separated by electrophoresis and electroblotted. The blots were then treated with monoclonal antibodies followed by incubation with peroxidaseconjugated goat anti-mouse IgG antibody (Jackson Immuno Research). Chemiluminescence detection was performed according to the manufacturer's instructions (Amersham).

\section{PCR amplification of genomic DNA and RT-PCR}

Genomic DNA was prepared as follows: cells grown in 6-well plates were collected in $500 \mu \mathrm{l}$ of lysis buffer $(50 \mathrm{mM}$ Tris- $\mathrm{HCl} \mathrm{pH} 8.0$, $200 \mathrm{mM} \mathrm{NaCl}, 5 \mathrm{mM}$ EDTA, $1 \%$ SDS and $0.2 \mathrm{mg} / \mathrm{ml}$ proteinase $\mathrm{K}$ ) and incubated overnight at $55^{\circ} \mathrm{C}$. The lysate was extracted with phenol/ chloroform and chloroform and precipitated with ethanol at room temperature. PCR amplifications were performed in $50 \mu \mathrm{l}$ reactions containing $67 \mathrm{mM}$ Tris- $\mathrm{HCl}$ pH $8.8,16 \mathrm{mM}\left(\mathrm{NH}_{4}\right)_{2} \mathrm{SO}_{4}, 10 \mathrm{mM}$ $\beta$-mercaptoethanol, $1.5 \mathrm{mM} \mathrm{MgCl} 2,10 \%$ DMSO, $0.2 \mathrm{mM}$ dNTPs, primers (12.5 pmol each), $1 \mu \mathrm{l}$ of proteinase K-treated cell extract or $20 \mathrm{ng}$ of purified genomic DNA and $2.5 \mathrm{U}$ Taq polymerase. The amplification conditions were: $94^{\circ} \mathrm{C}$ for 5 min followed by 35 cycles at $94^{\circ} \mathrm{C}$ for $30 \mathrm{~s}$ and $55^{\circ} \mathrm{C}$ for $30 \mathrm{~s}$, and finally one cycle at $94^{\circ} \mathrm{C}$ for $30 \mathrm{~s}$, $50^{\circ} \mathrm{C}$ for $30 \mathrm{~s}$ and $72^{\circ} \mathrm{C}$ for $5 \mathrm{~min}$.

Cytoplasmic RNA extraction following cell lysis with $0.5 \%$ NP-40 
and semi-quantitative RT-PCRs were performed as described (Chiba et al., 1997b). The PCR primers used for amplification of the different transcripts are available upon request. To make sure that amplifications were in the linear range, aliquots of PCR products were taken from each reaction at three different cycles between cycles 15 and 25, depending on the gene analysed (Freeman et al., 1994). Control experiments were performed to determine the range of PCR cycles over which amplification efficiency remained linear and to verify that the amount of PCR product was directly proportional to the amount of input RNA (data not shown). End-labelled oligonucleotides were generated for probing the PCR products on Southern blots. Transcript levels were quantified with a BAS 2000 bio-imaging analyser (Fuji Ltd) and were normalized to the corresponding HPRT levels.

\section{Analysis of F9 cell growth and differentiation}

Cells were seeded in 10-cm culture dishes at a density of $10^{4}$ cells/well at day zero, in the presence or absence of $1 \mu \mathrm{g} / \mathrm{ml}$ Dox. The medium was changed every second day, and $1 \mu \mathrm{M} \mathrm{RA}$ or $1 \mu \mathrm{M} \mathrm{RA}+250 \mu \mathrm{M}$ $\mathrm{bt}_{2} \mathrm{cAMP}$ was added as indicated. Cells were counted with a particle counter (Coulter Z2) and their differentiation status was examined under light microscopy as described (Clifford et al., 1996).

\section{Flow cytometric quantitation of cell cycle and apoptosis, and extraction of low mol. wt DNA}

Flow cytometric quantitation of cell cycle was carried out as described in Clifford et al. (1996), except that instead of ethidium bromide, propidum iodide (PI) was used at a final concentration of $25 \mu \mathrm{g} / \mathrm{ml}$. Flow cytometric quantitation of apoptosis using annexin $\mathrm{V}$ together with PI was as described (Lecoeur and Gougeon, 1996; Philippe et al., 1997). PI stains non-fixed cells in late-apoptotic and necrotic stages as these cells have lost their membrane inegrity. Briefly, $0.2 \times 10^{6}$ cells were resuspended in $50 \mu \mathrm{l}$ of $\mathrm{AV}$ buffer $(10 \mathrm{mM}$ HEPES-NaOH pH 7.4, $150 \mathrm{mM} \mathrm{NaCl}, 5 \mathrm{mM} \mathrm{KCl}, 1 \mathrm{mM} \mathrm{MgCl}_{2}$ and $1.8 \mathrm{mM} \mathrm{CaCl}_{2}$ ) and incubated with $1 \mu \mathrm{l}$ FITC-labelled AV (CALTAG Laboratories) for $30 \mathrm{~min}$ at room temperature in the dark. Five hundred microlitres of AV buffer containing $5 \mu \mathrm{g} / \mathrm{ml}$ PI was added for $5 \mathrm{~min}$ (in the dark) and the samples were analysed on a FACScan (Beckton Dickinson) equipped with a single argon ion laser. A minimum of 10000 cells per sample were analysed with the CELLQuest software (Beckton Dickinson).

Extraction of low mol. wt DNA from apoptotic cells was done in $0.2 \mathrm{M}$ phosphate-citrate buffer $\mathrm{pH} 7.8$, as described by Gong et al. (1994).

\section{Acknowledgements}

We thank P.Chambon for his continuous support. We are grateful to J.M.Garnier for the ES cell library, to C.Waltzinger for help in the flow cytometry studies, to P.Bouillet, J.Brocard, H.Bujard, H.Chiba, S.Girardin, X.Jacq, M.Lieb, Y.Lutz, J.Mountford and C.Rochette-Egly for reagents and advice. We also thank the cell culture group for providing cells, F.Ruffenach for oligonucleotide synthesis, and R.Buchert, B.Boulay and J.M.Lafontaine for preparing the figures. This work was supported by funds from the Institut National de la Santé et de la Recherche Médicale, the Centre National de la Recherche Scientifique, the Hôpital Universitaire de Strasbourg, the Association pour la Recherche sur le Cancer, the Fondation pour la Recherche Médicale, the Ligue Nationale Contre le Cancer, the Comité Départemental du HautRhin de la Ligue National Contre le Cancer and the Human Frontier Science Program.

\section{References}

Apone,L.M., Virbasius,C.M., Reese,J.C. and Green,M.R. (1996) Yeast $\mathrm{TAF}_{\mathrm{II}} 90$ is required for cell-cycle progression through $\mathrm{G}_{2} / \mathrm{M}$ but not for general transcription activation. Genes Dev., 10, 2368-2380.

Bartek,J., Bartkova,J. and Lukas,J. (1997) The retinoblastoma protein pathway in cell cycle control and cancer. Exp. Cell Res., 237, 1-6.

Bell,B. and Tora,L. (1999) Regulation of gene expression by multiple forms of TFIID and other novel $\mathrm{TAF}_{\mathrm{II}}$-containing complexes. Exp. Cell. Res., 246, 11-19.

Brand,M., Yamamoto,K., Staub,A. and Tora,L. (1999) Identification of $\mathrm{TBP}$-free $\mathrm{TAF}_{\mathrm{II}}$-containing complex subunits suggests a role in nucleosome acetylation and signal transduction. J. Biol. Chem., 274, 18285-18289.

Chiba,H., Clifford,J., Metzger,D. and Chambon,P. (1997a) Specific and redundant functions of retinoid $\mathrm{X}$ receptor/retinoic acid receptor heterodimers in differentiation, proliferation and apoptosis of F9 embryonal carcinoma cells. J. Cell Biol., 139, 735-747.

Chiba,H., Clifford,J., Metzger,D. and Chambon,P. (1997b) Distinct retinoid X receptor/retinoic acid receptor heterodimers are differentially involved in the control of expression of retinoid target genes in F9 embryonal carcinoma cells. Mol. Cell. Biol., 17, 30133020.

Clifford,J., Chiba,H., Sobieszczuk,D., Metzger,D. and Chambon,P. (1996) RXR $\alpha$-null F9 embryonal carcinoma cells are resistant to the differentiation, anti-proliferative and apoptotic effects of retinoids. EMBO J., 15, 4142-4155.

Freeman,R.S., Estus,S. and Johnson,E.M.,Jr (1994) Analysis of cell cyclerelated gene expression in postmitotic neurons: selective induction of Cyclin D1 during programmed cell death. Neuron, 12, 343-355.

Gong,J., Traganos,F. and Darzynkiewicz,Z. (1994) A selective procedure for DNA extraction from apoptotic cells applicable for gel electrophoresis and flow cytometry. Anal. Biochem., 218, 314-319.

Goodrich,J.A., Cutler,G. and Tjian,R. (1996) Contacts in context: promoter specificity and macromolecular interactions in transcription. Cell, 84, 825-830.

Gossen,M. and Bujard,H. (1992) Tight control of gene expression in mammalian cells by tetracycline-responsive promoters. Proc. Natl Acad. Sci. USA, 89, 5547-5551.

Gossen,M., Freundlieb,S., Bender,G., Muller,G., Hillen,W. and Bujard,H. (1995) Transcriptional activation by tetracyclines in mammalian cells. Science, 268, 1766-1769.

Grant,P.A., Schieltz,D., Pray-Grant,M.G., Steger,D.J., Reese,J.C., Yates,J.R. and Workman,J.L. (1998) A subset of $\mathrm{TAF}_{\mathrm{II}} \mathrm{S}$ are integral components of the SAGA complex required for nucleosome acetylation and transcriptional stimulation. Cell, 94, 45-53.

Hatakeyama,M., Brill,J.A., Fink,G.R. and Weinberg,R.A. (1994) Collaboration of $G_{1}$ cyclins in the functional inactivation of the retinoblastoma protein. Genes Dev., 8, 1759-1771.

Jacq,X., Brou,C., Lutz,Y., Davidson,I., Chambon,P. and Tora,L. (1994) Human $\mathrm{TAF}_{\mathrm{II}} 30$ is present in a distinct TFIID complex and is required for transcriptional activation by the estrogen receptor. Cell, 79, $107-117$.

Lecoeur,H. and Gougeon,M.L. (1996) Comparative analysis of flow cytometric methods for apoptosis quantitation in murine thymocytes and human peripheral lymphocytes from controls and HIV-infected persons. Evidence for interference by granulocytes and erythrocytes. J. Immunol. Methods, 198, 87-99.

Lundberg,A.S. and Weinberg,R.A. (1998) Functional inactivation of the retinoblastoma protein requires sequential modification by at least two distinct cyclin-cdk complexes. Mol. Cell. Biol., 18, 753-761.

May,M., Mengus,G., Lavigne,A.C., Chambon,P. and Davidson,I. (1996) Human $\mathrm{TAF}_{\mathrm{II}} 28$ promotes transcriptional stimulation by activation function 2 of the retinoid X receptors. EMBO J., 15, 3093-3104.

McBurney,M.W., Sutherland,L.C., Adra,C.N., Leclair,B., Rudnicki,M.A. and Jardine,K. (1991) The mouse Pgk-1 gene promoter contains an upstream activator sequence. Nucleic Acids Res., 19, 5755-5761.

Mengus,G., May,M., Jacq,X., Staub,A., Tora,L., Chambon,P. and Davidson,I. (1995) Cloning and characterization of $\mathrm{hTAF}_{\mathrm{II}} 18$, $\mathrm{hTAF}_{\mathrm{II}} 20$ and $\mathrm{hTAF}_{\mathrm{II}} 28$ : three subunits of the human transcription factor TFIID. EMBO J., 14, 1520-1531.

Mengus,G., May,M., Carre,L., Chambon,P. and Davidson,I. (1997) Human $\mathrm{TAF}_{\mathrm{II}} 135$ potentiates transcriptional activation by the AF- $2 \mathrm{~s}$ of the retinoic acid, vitamin D3 and thyroid hormone receptors in mammalian cells. Genes Dev., 11, 1381-1395.

Metzger,D., Clifford,J., Chiba,H. and Chambon,P. (1995) Conditional site-specific recombination in mammalian cells using a liganddependent chimeric Cre recombinase. Proc. Natl Acad. Sci. USA, 92, 6991-6995.

Moqtaderi,Z., Bai,Y., Poon,D., Weil,P.A. and Struhl,K. (1996a) TBPassociated factors are not generally required for transcriptional activation in yeast. Nature, $\mathbf{3 8 3}, 188-191$.

Moqtaderi,Z., Yale,J.D., Struhl,K. and Buratowski,S. (1996b) Yeast homologues of higher eukaryotic TFIID subunits. Proc. Natl Acad. Sci. USA, 93, 14654-14658.

Niforas,P., Chu,M.D. and Bird,P. (1996) A retinoic acid/cAMPresponsive enhancer containing a cAMP responsive element is required for the activation of the mouse thrombomodulin-encoding gene in differentiating F9 cells. Gene, 176, 139-147.

Ogryzko,V.V., Kotani,T., Zhang,X., Schlitz,R.L., Howard,T., Yang,X.J., Howard,B.H., Qin,J. and Nakatani,Y. (1998) Histone-like TAFs within the PCAF histone acetylase complex. Cell, 94, 35-44. 
Philippe,J., Louagie,H., Thierens,H., Vral,A., Cornelissen,M. and De Ridder,L. (1997) Quantification of apoptosis in lymphocyte subsets and effect of apoptosis on apparent expression of membrane antigens. Cytometry, 29, 242-249.

Pugh,B.F. and Tjian,R. (1991) Transcription from a TATA-less promoter requires a multisubunit TFIID complex. Genes Dev., 5, 1935-1945.

Reed,S.I. (1997) Control of the $\mathrm{G}_{1}-\mathrm{S}$ transition. Cancer Surv., 29, 7-23.

Sauer,B. and Henderson,N. (1990) Targeted insertion of exogenous DNA into the eukaryotic genome by the Cre recombinase. New Biol., 2 , 441-449.

Scheer,E., Mattei,M.G., Jacq,X., Chambon,P. and Tora,L. (1995) Organization and chromosomal localization of the gene (TAF2H) encoding the human TBP-associated factor II $30\left(\mathrm{TAF}_{\mathrm{II}} 30\right)$. Genomics, 29, 269-272.

Sekiguchi,T., Nohiro,Y., Nakamura,Y., Hisamoto,N. and Nishimoto,T. (1991) The human CCG1 gene, essential for progression of the $\mathrm{G}_{1}$ phase, encodes a 210-kilodalton nuclear DNA-binding protein. Mol. Cell. Biol., 11, 3317-3325.

Sherr,C.J. (1994) $\mathrm{G}_{1}$ phase progression: cycling on cue. Cell, 79, 551-555.

Strickland,S. and Mahdavi,V. (1978) The induction of differentiation in teratocarcinoma stem cells by retinoic acid. Cell, 15, 393-403.

Strickland,S., Smith,K.K. and Marotti,K.R. (1980) Hormonal induction of differentiation in teratocarcinoma stem cells: generation of parietal endoderm by retinoic acid and dibutyryl cAMP. Cell, 21, 347-355.

Sumi-Ichinose,C., Ichinose,H., Metzger,D. and Chambon,P. (1997) $S N F 2 \beta-B R G 1$ is essential for the viability of F9 murine embryonal carcinoma cells. Mol. Cell. Biol., 17, 5976-5986.

Suzuki-Yagawa,Y., Guermah,M. and Roeder,R.G. (1997) The ts13 mutation in the $\mathrm{TAF}_{\mathrm{II}} 250$ subunit $(C C G 1)$ of TFIID directly affects transcription of D-type cyclin genes in cells arrested in $\mathrm{G}_{1}$ at the nonpermissive temperature. Mol. Cell. Biol., 17, 3284-3294.

Tansey,W.P. and Herr,W. (1997) TAFs: guilt by association? Cell, 88, 729-732.

te Riele,H., Maandag,E.R., Clarke,A., Hooper,M. and Berns,A. (1990) Consecutive inactivation of both alleles of the pim-1 proto-oncogene by homologous recombination in embryonic stem cells. Nature, $\mathbf{3 4 8}$, 649-651.

Walker,S.S., Reese,J.C., Apone,L.M. and Green,M.R. (1996) Transcription activation in cells lacking $\mathrm{TAF}_{\mathrm{II}} \mathrm{S}$. Nature, 383, 185-188.

Walker,S.S., Shen,W.C., Reese,J.C., Apone,L.M. and Green,M.R. (1997) Yeast $\mathrm{TAF}_{\mathrm{II}} 145$ is required for transcription of $\mathrm{G}_{1} / \mathrm{S}$ cyclin genes and regulated by the cellular growth state. Cell, 90, 607-614.

Wang,E.H. and Tjian,R. (1994) Promoter-selective transcriptional defect in cell cycle mutant ts 13 rescued by $\mathrm{hTAF}_{\mathrm{II}} 250$. Science, 263, 811-814.

Wang,E.H., Zou,S. and Tjian,R. (1997) TAF 250 -dependent transcription of cyclin A is directed by ATF activator proteins. Genes Dev., 11, $2658-2669$.

White,J., Brou,C., Wu,J., Lutz,Y., Moncollin,V. and Chambon,P. (1992) The acidic transcriptional activator GAL-VP16 acts on preformed template-committed complexes. EMBO J., 11, 2229-2240.

Wieczorek,E., Brand,M., Jacq,X. and Tora,L. (1998) Function of $\mathrm{TAF}_{\mathrm{II}^{-}}$ containing complex without TBP in transcription by RNA polymerase II. Nature, 393, 187-191.

Yamit-Hezi,A. and Dikstein,R. (1998) $\mathrm{TAF}_{\mathrm{II}} 105$ mediates activation of anti-apoptotic genes by NF-אB. EMBO J., 17, 5161-5169.

Zhou,J., Zwicker,J., Szymanski,P., Levine,M. and Tjian,R. (1998) TAF mutations disrupt dorsal activation in the Drosophila embryo. Proc. Natl Acad. Sci. USA, 95, 13483-13488.

Zhou,Q., Lieberman,P.M., Boyer,T.G. and Berk,A.J. (1992) Holo-TFIID supports transcriptional stimulation by diverse activators and from a TATA-less promoter. Genes Dev., 6, 1964-1974.

Received June 1, 1999; revised and accepted July 8, 1999 